\title{
Investigating the effect of El Niño on nitrous oxide distribution in the eastern tropical South Pacific
}

\author{
Qixing Ji ${ }^{1}$, Mark A. Altabet ${ }^{2}$, Hermann W. Bange ${ }^{1}$, Michelle I. Graco ${ }^{3}$, Xiao Ma ${ }^{1}$, Damian L. Arévalo-Martínez ${ }^{1}$, and \\ Damian S. Grundle ${ }^{1,4}$ \\ ${ }^{1}$ GEOMAR Helmholtz Centre of Ocean Research Kiel, Kiel, 24105, Germany \\ ${ }^{2}$ School for Marine Science \& Technology, University of Massachusetts Dartmouth, New Bedford, Massachusetts, USA \\ ${ }^{3}$ Dirección General de Investigaciones Oceanográficas y cambio Climático, Instituto del Mar del Perú (IMARPE), \\ P.O. Box 22, Callao, Perú \\ ${ }^{4}$ Bermuda Institute of Ocean Sciences, St. George's, GE01, Bermuda
}

Correspondence: Qixing Ji (qji@geomar.de)

Received: 19 October 2018 - Discussion started: 6 November 2018

Revised: 29 April 2019 - Accepted: 2 May 2019 - Published: 17 May 2019

\begin{abstract}
The open ocean is a major source of nitrous oxide $\left(\mathrm{N}_{2} \mathrm{O}\right)$, an atmospheric trace gas attributable to global warming and ozone depletion. Intense sea-to-air $\mathrm{N}_{2} \mathrm{O}$ fluxes occur in major oceanic upwelling regions such as the eastern tropical South Pacific (ETSP). The ETSP is influenced by the El Niño-Southern Oscillation that leads to inter-annual variations in physical, chemical, and biological properties in the water column. In October 2015, a strong El Niño event was developing in the ETSP; we conduct field observations to investigate (1) the $\mathrm{N}_{2} \mathrm{O}$ production pathways and associated biogeochemical properties and (2) the effects of El Niño on water column $\mathrm{N}_{2} \mathrm{O}$ distributions and fluxes using data from previous non-El Niño years. Analysis of $\mathrm{N}_{2} \mathrm{O}$ natural abundance isotopomers suggested that nitrification and partial denitrification (nitrate and nitrite reduction to $\mathrm{N}_{2} \mathrm{O}$ ) were occurring in the near-surface waters; indicating that both pathways contributed to $\mathrm{N}_{2} \mathrm{O}$ effluxes. Higher-than-normal sea surface temperatures were associated with a deepening of the oxycline and the oxygen minimum layer. Within the shelf region, surface $\mathrm{N}_{2} \mathrm{O}$ supersaturation was nearly an order of magnitude lower than that of non-El Niño years. Therefore, a significant reduction of $\mathrm{N}_{2} \mathrm{O}$ efflux $(75 \%-95 \%)$ in the ETSP occurred during the $2015 \mathrm{El} \mathrm{Niño.} \mathrm{At} \mathrm{both} \mathrm{offshore}$ and coastal stations, the $\mathrm{N}_{2} \mathrm{O}$ concentration profiles during El Niño showed moderate $\mathrm{N}_{2} \mathrm{O}$ concentration gradients, and the peak $\mathrm{N}_{2} \mathrm{O}$ concentrations occurred at deeper depths during El Niño years; this was likely the result of suppressed upwelling retaining $\mathrm{N}_{2} \mathrm{O}$ in subsurface waters. At multiple
\end{abstract}

stations, water-column inventories of $\mathrm{N}_{2} \mathrm{O}$ within the top $1000 \mathrm{~m}$ were up to $160 \%$ higher than those measured in nonEl Niño years, indicating that subsurface $\mathrm{N}_{2} \mathrm{O}$ during El Niño could be a reservoir for intense $\mathrm{N}_{2} \mathrm{O}$ effluxes when normal upwelling is resumed after El Niño.

\section{Introduction}

The El Niño-Southern Oscillation (ENSO) is a naturally occurring decadal climate cycle that affects the oceanic and atmospheric conditions across the equatorial Pacific (Philander, 1983). A pronounced effect of ENSO in the ocean is the redistribution of heat flux across the tropical and subtropical Pacific. Generally, the ENSO cycle can be divided into three phases, El Niño, La Niña, and neutral. During El Niño/La Niña years, higher/lower sea surface temperature and deepening/shoaling of the thermocline depth occur in the eastern tropical South Pacific (ETSP) (Barber and Chavez, 1983). During El Niño years, upwelling is suppressed in the ETSP, and thus reduces upward nutrient fluxes to the surface waters causing decreased primary production (Chavez et al., 2003; Niquen and Bouchon, 2004; Graco et al., 2017).

The ETSP is an oceanic region with intense sea-to-air flux of nitrous oxide $\left(\mathrm{N}_{2} \mathrm{O}\right)$, a strong greenhouse gas and a potent ozone-depleting agent in the 21st century (Ravishankara et al., 2009). Diverse microbial processes involved in the production and consumption of $\mathrm{N}_{2} \mathrm{O}$ occur in the ETSP, a major 
oceanic oxygen minimum zone (OMZ) having a wide range of $\mathrm{O}_{2}$ concentrations spanning the sub-nanomolar level at intermediate depths (Revsbech et al., 2009) to atmospheric saturation at the surface. In the presence of oxygen, $\mathrm{N}_{2} \mathrm{O}$ is a by-product during the first step of nitrification, i.e., ammonium $\left(\mathrm{NH}_{4}^{+}\right)$oxidation to nitrite $\left(\mathrm{NO}_{2}^{-}\right)$(Anderson, 1964). Under suboxic and anoxic conditions, $\mathrm{N}_{2} \mathrm{O}$ is produced via partial denitrification, i.e., $\mathrm{NO}_{2}^{-}$reduction and nitrate $\left(\mathrm{NO}_{3}^{-}\right)$ reduction (Codispoti and Christensen, 1985). Partial denitrification can be mediated by denitrifying bacteria using $\mathrm{NO}_{2}^{-}$ and $\mathrm{NO}_{3}^{-}$as substrates, as well as nitrifying bacteria using only $\mathrm{NO}_{2}^{-}$, a process termed nitrifier-denitrification (Frame and Casciotti, 2010; Trimmer et al., 2016). The dominant biological sink of $\mathrm{N}_{2} \mathrm{O}$ in the ocean is the last step of denitrification where $\mathrm{N}_{2} \mathrm{O}$ is reduced to $\mathrm{N}_{2}$ under anoxic conditions (Codispoti and Christensen, 1985). Recent investigations suggest that $\mathrm{N}_{2} \mathrm{O}$ uptake by diazotrophs is another possible $\mathrm{N}_{2} \mathrm{O}$ sink occurring at the surface waters (Farías et al., 2013; Cornejo et al., 2015). Its environmental significance awaits further exploration.

Research on the impact of ENSO on $\mathrm{N}_{2} \mathrm{O}$ dynamics was initiated by the observation of significant reduction in oceanic $\mathrm{N}_{2} \mathrm{O}$ effluxes during El Niño events (Cline et al., 1987; Butler et al., 1989). Recent model simulations demonstrated that ENSO events could induce lower denitrification rates, higher nitrification rates, and lower $\mathrm{N}_{2} \mathrm{O}$ fluxes (Mogollón and Calil, 2017; Yang et al., 2017), which could be related to changes in $\mathrm{O}_{2}$ and organic matter availabilities that are critical environmental factors regulating $\mathrm{N}_{2} \mathrm{O}$ production (Elkins et al., 1978; Farías et al., 2009; ArévaloMartínez et al., 2015; Kock et al., 2016). Here we report water column hydrography, nitrogen biogeochemistry, and $\mathrm{N}_{2} \mathrm{O}$ distribution during October 2015 when a strong El Niño event (recurrence interval $>10$ years) was developing (Stramma et al., 2016; Santoso et al., 2017). The natural abundance isotopomers of $\mathrm{N}_{2} \mathrm{O}$, i.e., the intramolecular configuration of stable isotopes $\left({ }^{15} \mathrm{~N}\right.$ vs. ${ }^{14} \mathrm{~N}$ and ${ }^{18} \mathrm{O}$ vs. ${ }^{16} \mathrm{O}$ ), were used to determine the pathways of $\mathrm{N}_{2} \mathrm{O}$ production and consumption by a simple mass balance model outlined previously (Yamagishi et al., 2007; Grundle et al., 2017). Finally, the effects of a strong El Niño event on the surface and water column $\mathrm{N}_{2} \mathrm{O}$ distributions were investigated by incorporating archived ETSP datasets that demonstrated contrasting hydrography and biogeochemistry between El Niño and nonEl Niño years.

\section{Materials and methods}

\subsection{Field sampling and laboratory measurements}

The progress and the strength of El Niño was quantified by the Ocean Niño Index (ONI, Fig. 1), defined as the running 3month average sea surface temperature anomaly for the Niño 3.4 region in the east-central tropical Pacific $\left(5^{\circ} \mathrm{S}-5^{\circ} \mathrm{N}\right.$,

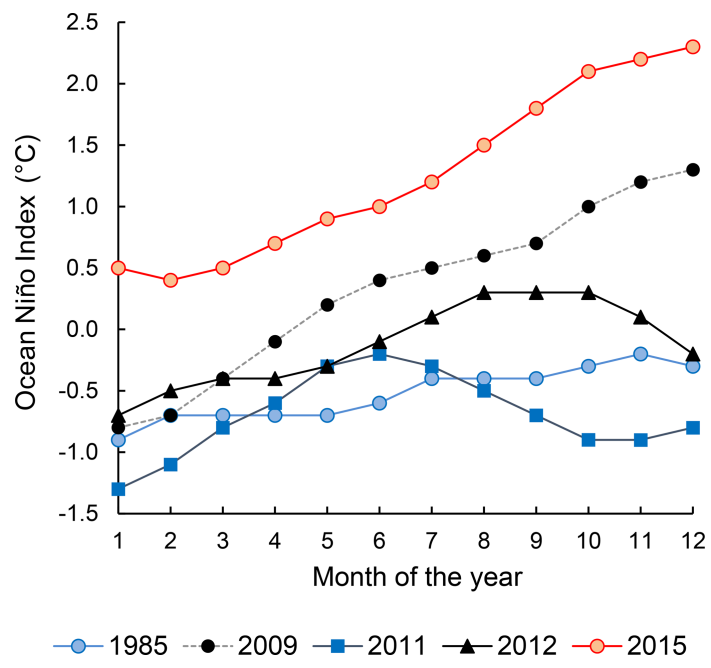

Figure 1. Ocean Niño Index of the years 1985 (weak La Niña), 2009 (neutral), 2011 (weak La Niña), 2012 (neutral), and 2015 (strong El Niño). Data were downloaded from http://origin.cpc.ncep.noaa. gov/products/analysis_monitoring/ensostuff/ONI_v5.php (last access: 15 October 2018).

$\left.120-170^{\circ} \mathrm{W}\right)$. The $2015-2016$ El Niño was a "strong El Niño event" indicated by $\mathrm{ONI} \geq 0.5^{\circ} \mathrm{C}$ from November 2014 to May 2016. This study was conducted on the ASTRA-OMZ SO243 cruise on board the R/V Sonne between 5 and 22 October 2015 from Guayaquil, Ecuador, to Antofagasta, Chile (Fig. 2a). In October 2015, the El Niño was still developing with $\mathrm{ONI}=2.1^{\circ} \mathrm{C}$, comparable to other strong El Niño events in 1972-1973, 1982-1983, and 1997-1998 (Stramma et al., 2016).

The sampling stations are categorized into offshore (Fig. 2a in red polygon) and coastal (Fig. 2a white polygon) according to their respective water depth: the coastal stations are shallower than $250 \mathrm{~m}$ whereas the offshore stations are $>3000 \mathrm{~m}$ in depth. Water samples were taken from a $24 \times 10 \mathrm{~L}$ bottle CTD rosette system. At every station, CTD Niskin bottles collected water samples at 10-20 depths spanning the observed oxygen concentration range. The CTD system was equipped with two independent sets of sensors for temperature, conductivity (salinity), and oxygen measurements. Calibrations for temperature, salinity, and oxygen measurements were reported previously, with standard deviations of $0.002^{\circ} \mathrm{C}, 0.0011 \mathrm{PSU}$, and $0.8 \mu \mathrm{mol} \mathrm{L}^{-1}\left[\mathrm{O}_{2}\right]$, respectively (Stramma et al., 2016). The detection limit of dissolved oxygen was $\sim 3 \mu \mathrm{mol} \mathrm{L}-1$; the oxygen-deficient zone (ODZ) was operationally defined as water parcels with $\left[\mathrm{O}_{2}\right]<5 \mu \mathrm{mol} \mathrm{L}{ }^{-1}$, and the upper and lower oxycline boundary layer was defined as $\left[\mathrm{O}_{2}\right]=20 \mu \mathrm{mol} \mathrm{L}^{-1}$ isoline occurring above and below the ODZ, respectively. Saturation level of $\mathrm{O}_{2}$ was calculated with in situ temperature and salinity according to Garcia and Gordon (1992). Dissolved $\mathrm{NO}_{3}^{-}$and $\mathrm{NO}_{2}^{-}$concentrations were measured at sea with an autoanalyzer (QuAAtro, Seal Analytical, Germany). Chemical 
analyses of $\mathrm{NO}_{3}^{-}$and $\mathrm{NO}_{2}^{-}$had detection limits of 0.1 and $0.02 \mu \mathrm{mol} \mathrm{L}^{-1}$, respectively. For $\mathrm{N}_{2} \mathrm{O}$ concentration measurements, triplicate samples were collected in $20 \mathrm{~mL}$ brown glass vials and were crimp-sealed with butyl stoppers and aluminum caps. Immediately following this, a $10 \mathrm{~mL}$ helium headspace was created and $50 \mu \mathrm{L}$ of saturated mercuric chloride $\left(\mathrm{HgCl}_{2}\right)$ solution was added. After an equilibration period of at least $2 \mathrm{~h}$, the headspace sample $(10 \mathrm{~mL})$ was measured by a gas chromatograph equipped with an electron capture detector (GC/ECD) that was calibrated on a daily basis using dilutions of two standard gas mixtures. The detailed GC/ECD setup and calculation of $\mathrm{N}_{2} \mathrm{O}$ concentration were reported previously (Walter et al., 2006; Kock et al., 2016). For the $\mathrm{N}_{2} \mathrm{O}$ concentration data of the 2015 cruise, the standard deviation of triplicate sampling was $1 \%-8 \%$, generally $<2.5 \mathrm{nmol} \mathrm{L}^{-1}$.

Water column $\mathrm{N}_{2} \mathrm{O}$ saturation was quantified by the $\mathrm{N}_{2} \mathrm{O}$ excess $\left(\Delta \mathrm{N}_{2} \mathrm{O}\right)$, defined as the concentration difference between measured and equilibrium values:

$\Delta \mathrm{N}_{2} \mathrm{O}=\left[\mathrm{N}_{2} \mathrm{O}\right]_{\text {measured }}-\left[\mathrm{N}_{2} \mathrm{O}\right]_{\text {equilibrium. }}$.

The $\mathrm{N}_{2} \mathrm{O}$ equilibrium concentration was calculated according to Weiss and Price (1980) with in situ temperature, salinity, and the atmospheric $\mathrm{N}_{2} \mathrm{O}$ dry mole fraction in the year of 2015,328 ppb at 1 atmospheric pressure (Blasing, 2016). The $\mathrm{N}_{2} \mathrm{O}$ efflux from the ocean to the atmosphere was calculated as the product of $\mathrm{N}_{2} \mathrm{O}$ excess and gas transfer coefficient $\left(k_{w}\right.$, $\mathrm{cm} \mathrm{h}^{-1}$ ) that was derived according to the empirical relationship proposed by Wanninkhof (2014):

$k_{w}=0.251 \times U_{10}^{2} \times(S c / 660)^{-0.5}$,

where $U_{10}$ denotes wind speed $\left(\mathrm{m} \mathrm{s}^{-1}\right)$ at $10 \mathrm{~m}$ above sea surface, and Sc denotes the Schmidt number for $\mathrm{N}_{2} \mathrm{O}$ under in situ temperature (Wanninkhof, 2014).

Samples for natural abundance $\mathrm{N}_{2} \mathrm{O}$ isotopes and isotopomers were collected in $160 \mathrm{~mL}$ glass serum bottles with butyl stoppers and aluminum seals and preserved with $100 \mu \mathrm{L}$ of saturated $\mathrm{HgCl}_{2}$. Isotopomeric measurements of $\mathrm{N}_{2} \mathrm{O}$ were carried out at the University of Massachusetts Dartmouth following procedures previously reported (Grundle et al., 2017). In brief, dissolved $\mathrm{N}_{2} \mathrm{O}$ was extracted by an automated purge-and-trap system and concentrated with liquid nitrogen. Interfering molecules such as $\mathrm{H}_{2} \mathrm{O}$ and $\mathrm{CO}_{2}$ were isolated from $\mathrm{N}_{2} \mathrm{O}$ to increase measurement precision. A multi-collector isotope ratio mass spectrometer detected intact $\mathrm{N}_{2} \mathrm{O}$ molecule mass ratios of $45 / 44$ and $46 / 44$ and a $\mathrm{NO}^{+}$fragment mass ratios $31 / 30$. Relative abundance of $\mathrm{N}_{2} \mathrm{O}$ isotopomers was expressed using the delta notation $(\delta X)$, defined as the relative difference between isotopic ratio $(R)$ of sample and reference material:

$\delta X=\left(\frac{R_{\text {sample }}}{R_{\text {reference }}}-1\right) \times 1000$,

where $X$ denotes ${ }^{15} \mathrm{~N}_{\alpha},{ }^{15} \mathrm{~N}_{\beta}$, and ${ }^{18} \mathrm{O}$, and $R$ denotes the ${ }^{15} \mathrm{~N} /{ }^{14} \mathrm{~N}$ at the central $(\alpha)$ and terminal $(\beta)$ nitrogen posi- tions and ${ }^{18} \mathrm{O} /{ }^{16} \mathrm{O}$ at oxygen position of the $\mathrm{N}_{2} \mathrm{O}$ molecule. The value of $\delta X$ is expressed as per mill $(\% o)$ deviation relative to a set of reference materials: atmospheric $\mathrm{N}_{2}$ for $\delta^{15} \mathrm{~N}_{\text {bulk }}, \delta^{15} \mathrm{~N}_{\alpha}$, and $\delta^{15} \mathrm{~N}_{\beta}$ (Mohn et al., 2014), and Vienna standard mean ocean water (VSMOW) for $\delta^{18} \mathrm{O}$. Therefore, mass ratios of $45 / 44,46 / 44$, and $31 / 30$ determined $\delta^{15} \mathrm{~N}_{\text {bulk }}$ (conventionally $\delta^{15} \mathrm{~N}$ ), $\delta^{18} \mathrm{O}$, and $\delta^{15} \mathrm{~N}_{\alpha}$, respectively. The $\delta^{15} \mathrm{~N}_{\beta}$, the relative abundance of $\mathrm{N}_{2} \mathrm{O}$ molecule with ${ }^{15} \mathrm{~N}$ substitution at the terminal $(\beta)$ position, was calculated by $\delta^{15} \mathrm{~N}_{\beta}=2 \times \delta^{15} \mathrm{~N}_{\text {bulk }}-\delta^{15} \mathrm{~N}_{\alpha}$. Site preference (SP) is defined as follows:

$\mathrm{SP}=\delta^{15} \mathrm{~N}_{\alpha}-\delta^{15} \mathrm{~N}_{\beta}$.

Calibration of $\delta^{15} \mathrm{~N}_{\alpha}-\mathrm{N}_{2} \mathrm{O}, \delta^{15} \mathrm{~N}_{\beta}-\mathrm{N}_{2} \mathrm{O}$, and $\delta^{18} \mathrm{O}-\mathrm{N}_{2} \mathrm{O}$ was accomplished using four certified standard gases (supplied by Joachim Mohn; see Table S2 in the Supplement) encompassing the values reported here. The analytical precision of isotope measurements was $\pm 0.07,0.17,0.36$, and $0.18 \%$ for $\delta^{15} \mathrm{~N}_{\text {bulk }}-\mathrm{N}_{2} \mathrm{O}, \delta^{15} \mathrm{~N}_{\alpha}-\mathrm{N}_{2} \mathrm{O}, \delta^{15} \mathrm{~N}_{\beta}-\mathrm{N}_{2} \mathrm{O}$, and $\delta_{18} \mathrm{O}-\mathrm{N}_{2} \mathrm{O}$, respectively.

\subsection{Additional datasets}

The twice-weekly, $50 \mathrm{~km}$ resolution of sea surface temperature anomaly data from NOAA's Satellite Coral Bleaching Monitoring Datasets (https://coralreefwatch.noaa.gov/ satellite/methodology/methodology.php, last access: 15 October 2018) were used to quantify the sea surface temperature difference of the ETSP during October 2015 relative to 1985-1993. For $\mathrm{N}_{2} \mathrm{O}$ flux calculations, instantaneous wind speed data at each of our sampling locations were acquired from shipboard metrological measurements. Seawater $\mathrm{N}_{2} \mathrm{O}$ and oxygen concentrations from previous sampling campaigns in the ETSP were extracted from the MEMENTO database (Kock and Bange, 2015). Specifically, data from the following cruises were used for comparison between El Niño and non-El Niño years: NITROP-85 (February 1985), M77/3 (January 2009), Callao Time Series Transect (October 2011), M90 (November 2012), M91 (December 2012), and AT26-26 (January 2015). The ONI of these years (1985, 2009, 2011, 2012, Fig. 1) indicated that 1985 and 2011 are considered weak La Niña years, whereas 2009 and 2012 are considered neutral years. The MEMENTO database has not archived any $\mathrm{N}_{2} \mathrm{O}$ datasets in the ETSP region during previous El Niño events, and therefore we were not able to compare $\mathrm{N}_{2} \mathrm{O}$ dynamics between two El Niño time periods. To facilitate the comparison, the 2015 and archived $\mathrm{N}_{2} \mathrm{O}$ depth profiles were compared at three offshore and three coastal locations, each within a grid space of $0.75^{\circ} \times 0.75^{\circ}$ (see Table $\mathrm{S} 1$ for station coordinates). Standard deviations of repeated $\mathrm{N}_{2} \mathrm{O}$ concentration measurements (analytical precision) for archived $\mathrm{N}_{2} \mathrm{O}$ concentration datasets were retrieved from respective references (see Table $\mathrm{S} 1$ ). These analytical precisions are $<5 \%$ of $\mathrm{N}_{2} \mathrm{O}$ concentration values. 
(a)

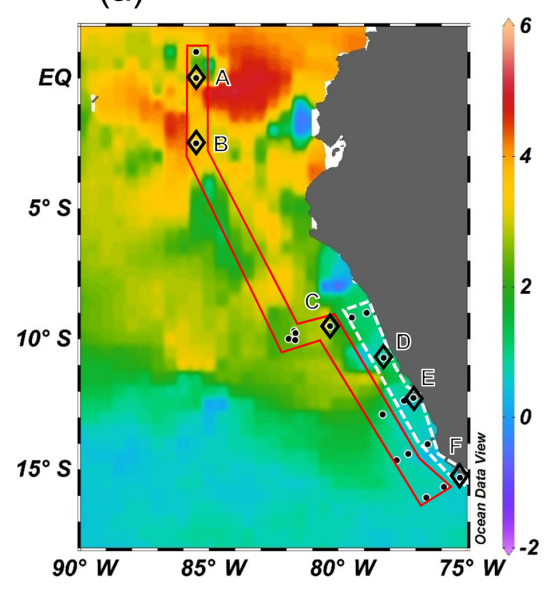

(b)

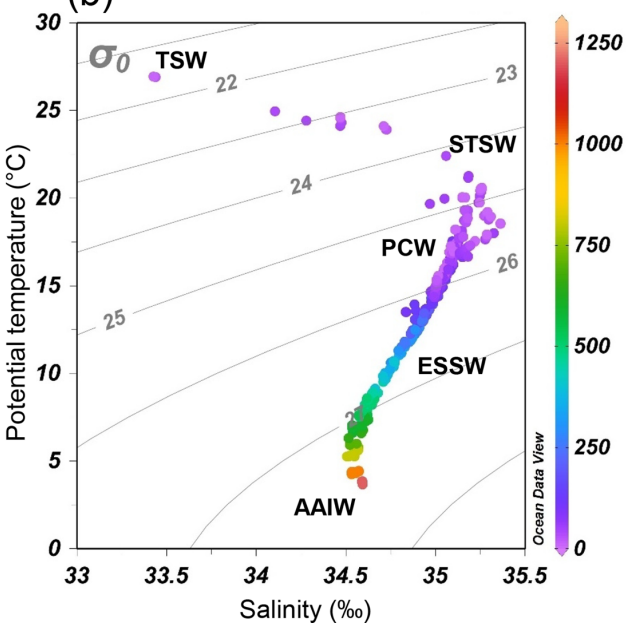

Figure 2. (a) Monthly mean sea surface temperature anomaly $\left({ }^{\circ} \mathrm{C}\right)$ of October 2015 from NOAA's Satellite Coral Bleaching Monitoring Datasets. Sampling stations (filled circles) are categorized as "offshore" (in red polygon) and "coastal" sections (in white polygon). Comparative analyses of water column $\mathrm{N}_{2} \mathrm{O}$ (see Sect. 4.3) were performed at stations A-E (open diamonds). (b) Potential temperature-salinity diagram, with corresponding depths (meters, color bar on right) and potential density $\left(\sigma_{\theta}, \mathrm{kg} \mathrm{m}^{-3}\right)$ of all sampling stations. Five water masses are shown: tropical surface water (TSW), subtropical surface water (STSW), Peru coastal water (PCW), equatorial subsurface water (ESSW), and Antarctic intermediate water (AAIW).

\section{Results}

\subsection{Hydrography, distribution of oxygen, and inorganic nitrogen}

The 2015-2016 El Niño event impacted the ETSP with a relatively high sea surface temperature anomaly, especially at the equatorial region $\left(2^{\circ} \mathrm{S}-2^{\circ} \mathrm{N}\right.$ and $\left.80-90^{\circ} \mathrm{W}\right)$ where the highest anomaly between 3 and $5^{\circ} \mathrm{C}$ was observed at offshore waters (Fig. 2a). The El Niño-induced warming effect decreased southwards. Between 5 and $12^{\circ} \mathrm{S}$, the temperature anomaly was $2-3^{\circ} \mathrm{C}$. South of $12^{\circ} \mathrm{S}$ the anomaly was generally $<1^{\circ} \mathrm{C}$. The shelf areas between 7 and $14^{\circ} \mathrm{S}$ had a progressively lower temperature anomaly southwards: $>1.5$ and $<1^{\circ} \mathrm{C}$ north and south of $12^{\circ} \mathrm{S}$.

Five water masses, based on their thermohaline indices (Strub et al., 1998; Silva et al., 2009), were identified (Fig. 2b). The northward-flowing Antarctic Intermediate water (AAIW, $T=3-5^{\circ} \mathrm{C}, S \approx 34.5$ ) was found at depths below $1000 \mathrm{~m}$. The equatorial subsurface water (ESSW, $T=8$ $12^{\circ} \mathrm{C}, S=34.7-34.9$ ) was near the Peruvian coast at depths between 300 and $400 \mathrm{~m}$. Above the continental slope (water depth $<250 \mathrm{~m}$ ), the colder Peru coastal water (PCW, $T<19^{\circ} \mathrm{C}, S \approx 35$ ) occupied $30-250 \mathrm{~m}$, whereas the warmer subtropical surface water (STSW, $T>18.5^{\circ} \mathrm{C}, S>34.9$ ) was found at depth $<30 \mathrm{~m}$. The surface water north of the Equator consisted of the tropical surface water (TSW), which had high temperature and low salinity $\left(T>25^{\circ} \mathrm{C}, S<33.5\right)$ due to excess precipitation. The October 2015 water column below $250 \mathrm{~m}$ had similar thermohaline properties compared to those of October-December 2012 (non-El Niño) that had been shown in an earlier study (Kock et al., 2016), except that October 2015 had $2-4^{\circ} \mathrm{C}$ warmer surface water.

Along the offshore section, the upper oxycline boundary $\left(\left[\mathrm{O}_{2}\right]=20 \mu \mathrm{mol} \mathrm{L}^{-1}\right.$ isoline $)$ was at $250-300 \mathrm{~m}$ along the Equator at $85.5^{\circ} \mathrm{W}$, and the $\mathrm{ODZ}\left(\left[\mathrm{O}_{2}\right]<5 \mu \mathrm{mol} \mathrm{L}^{-1}\right)$ appeared near $10^{\circ} \mathrm{S}$ (Fig. 3a). The southward shoaling of the oxycline, thickening of the ODZ, and shoaling of the $\left[\mathrm{NO}_{3}^{-}\right]=20 \mu \mathrm{mol} \mathrm{L}-1$ isoline were observed south of $10^{\circ} \mathrm{S}$ (Fig. 3a and b), where the thickness of the ODZ was $~$ $300 \mathrm{~m}$. The top of the ODZ reached $\sim 125 \mathrm{~m}$ between 13 and $16^{\circ} \mathrm{S}$. Significant accumulation of $\mathrm{NO}_{2}^{-}(>1 \mu \mathrm{mol} \mathrm{L}-1)$ occurred south of $10^{\circ} \mathrm{S}$ between 30 and $400 \mathrm{~m}$ within the ODZ (Fig. 3c), corresponding to lower $\mathrm{NO}_{3}^{-}$concentrations (Fig. 3b). The highest $\mathrm{NO}_{2}^{-}$concentration $\left(9.4 \mu \mathrm{mol} \mathrm{L}^{-1}\right)$ was recorded at $200 \mathrm{~m}$ at $15.7^{\circ} \mathrm{S}$.

Along the coastal section, the surface (upper $10 \mathrm{~m}$ ) $\mathrm{O}_{2}$ concentrations were below saturation at all sampling stations $\left(50 \%-97 \%\right.$ saturation). Surface $\mathrm{O}_{2}$ concentrations were $165-217 \mu \mathrm{mol} \mathrm{L}^{-1}$ north of $10^{\circ} \mathrm{S}$ and gradually decreased to $135-190 \mu \mathrm{mol} \mathrm{L}^{-1}$ between 10 and $12.5^{\circ} \mathrm{S}$ and to $120 \mu \mathrm{mol} \mathrm{L}^{-1}$ south of $14^{\circ} \mathrm{S}$ (Fig. 3d). The shoaling of the $\left[\mathrm{O}_{2}\right]=20 \mu \mathrm{mol} \mathrm{L}^{-1}$ isoline was observed south of $9^{\circ} \mathrm{S}$. The top of the ODZ was found at 200,150 , and $80 \mathrm{~m}$ at 11,12 , and $14^{\circ} \mathrm{S}$, respectively. The surface $\mathrm{NO}_{3}^{-}$concentrations were $11-23 \mu \mathrm{mol} \mathrm{L}{ }^{-1}$ between 9 and $16^{\circ} \mathrm{S}$, and the $\left[\mathrm{NO}_{3}^{-}\right]=20 \mu \mathrm{mol} \mathrm{L}^{-1}$ isoline was at $0-20 \mathrm{~m}$ (Fig. 3e). Water column $\mathrm{NO}_{2}^{-}$concentrations at coastal stations were generally below $1 \mu \mathrm{mol} \mathrm{L}^{-1}$, with the exception of the station at $14.0^{\circ} \mathrm{S}$ where $\mathrm{NO}_{2}^{-}$concentrations reached $1.2 \mu \mathrm{mol} \mathrm{L}-1$ below $200 \mathrm{~m}$ (Fig. 3f). 


\section{Offshore}

(a)
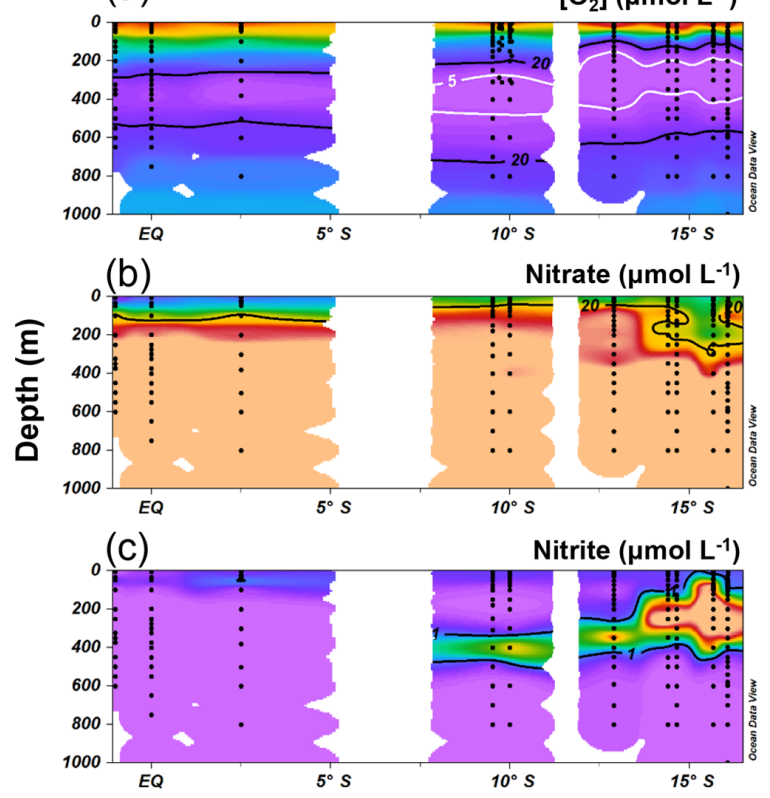

Coastal

(d)

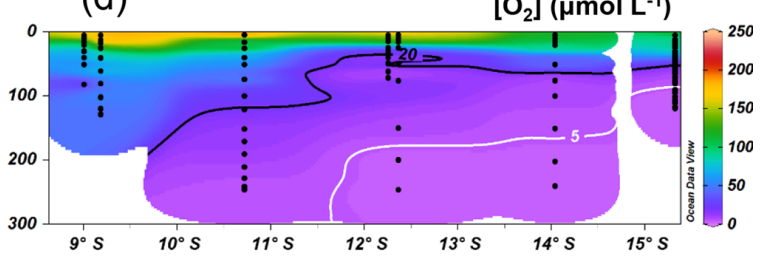

(e)
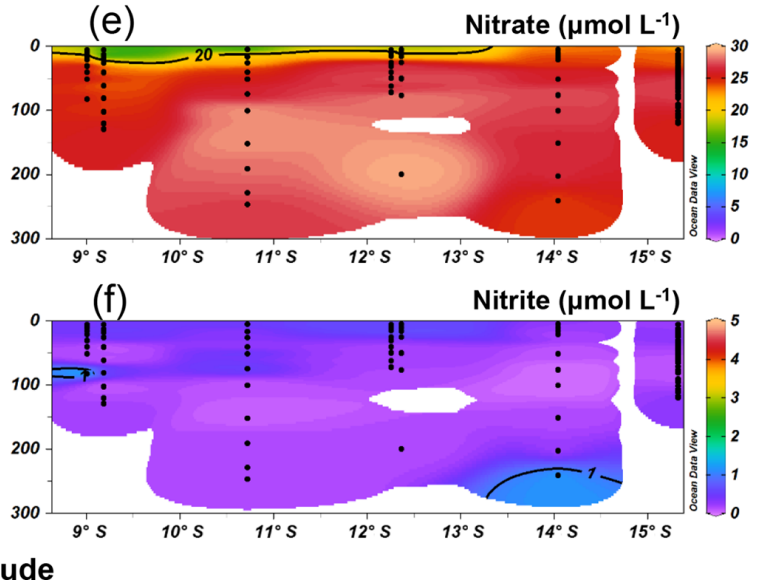

Figure 3. Water column oxygen $(\mathbf{a}, \mathbf{d})$, nitrate $(\mathbf{b}, \mathbf{e})$, and nitrite concentrations $(\mathbf{c}, \mathbf{f})$ along the offshore $(\mathbf{a}, \mathbf{b}, \mathbf{c})$ and coastal sections $(\mathbf{d}, \mathbf{e}, \mathbf{f})$ during October 2015.

\subsection{Water column $\mathrm{N}_{2} \mathrm{O}$ concentrations and isotopes}

Along the offshore section, the water column $\mathrm{N}_{2} \mathrm{O}$ distributions showed a southward increase in surface concentrations and southward decrease in subsurface concentration maxima (Fig. 4a). The equatorial region $\left(1^{\circ} \mathrm{N}\right.$ to $\left.2.5^{\circ} \mathrm{S}, 85.5^{\circ} \mathrm{W}\right)$ had subsurface $\mathrm{N}_{2} \mathrm{O}$ concentrations up to $93 \mathrm{nmol} \mathrm{L}^{-1}$ at thermocline depths (200-550 m); water column $\delta^{15} \mathrm{~N}$, SP, and $\delta^{18} \mathrm{O}$ generally increased with depth (Fig. $4 \mathrm{~b}, \mathrm{c}$ and d); at the subsurface $\mathrm{N}_{2} \mathrm{O}$ concentration maximum, $\delta^{15} \mathrm{~N}$, SP, and $\delta^{18} \mathrm{O}$ were $\sim 6 \%$, $13 \%$ - $17 \%$, and $45 \%$ - $50 \%$ o, respectively. Two $\mathrm{N}_{2} \mathrm{O}$ concentration maxima were observed at stations south of $10^{\circ} \mathrm{S}$ where the $\mathrm{ODZ}$ was formed. Near $10^{\circ} \mathrm{S}$, two $\mathrm{N}_{2} \mathrm{O}$ concentration maxima $\left(70 \pm 6 \mathrm{nmol} \mathrm{L}^{-1}\right)$ occurred between 200 and $600 \mathrm{~m}$; and a local concentration minimum $\left(\sim 30 \mathrm{nmol} \mathrm{L}^{-1}\right)$ occurred within the ODZ at $400 \mathrm{~m}$, associated with high $\delta^{15} \mathrm{~N}(8 \% 0-10 \%)$, SP $(20 \%-30 \%)$, and $\delta^{18} \mathrm{O}\left(60 \%\right.$ - $70 \%$ o). Near $13^{\circ} \mathrm{S}$, a shallow $\mathrm{N}_{2} \mathrm{O}$ concentration maximum $\left(\sim 80 \mathrm{nmol} \mathrm{L}^{-1}\right)$ occurred at $\sim 100 \mathrm{~m}$, and a local $\mathrm{N}_{2} \mathrm{O}$ concentration minimum $\left(18 \mathrm{nmol} \mathrm{L}^{-1}\right)$ occurred at $350 \mathrm{~m}$. Between 14 and $16^{\circ} \mathrm{S}$, the lowest $\left(<10 \mathrm{nmol} \mathrm{L}^{-1}\right)$ $\mathrm{N}_{2} \mathrm{O}$ concentrations were observed at $200-400 \mathrm{~m}$ within the ODZ, where the highest values of $\delta^{15} \mathrm{~N}(>10 \%)$, SP $(30 \%$ $40 \%$ ) and $\delta^{18} \mathrm{O}(>60 \%)$ were observed.

Along the coastal section, a southward increase in surface $\mathrm{N}_{2} \mathrm{O}$ concentration $\left(20 \mathrm{nmol} \mathrm{L}^{-1}\right.$ north of $11^{\circ} \mathrm{S}$ and $>40 \mathrm{nmol} \mathrm{L}^{-1}$ south of $13^{\circ} \mathrm{S}$ ) was observed, coinciding with southward shoaling of the ODZ (Fig. 4e). Subsurface maximum $\mathrm{N}_{2} \mathrm{O}$ concentrations were observed below $200 \mathrm{~m}$ near $10.7^{\circ} \mathrm{S}$ and at $80-90 \mathrm{~m}$ south of $12^{\circ} \mathrm{S}$, where ODZ was formed. The $\delta^{15} \mathrm{~N}$ values in coastal waters were between 2.5 and $5 \%$, with lower values at stations south of $14{ }^{\circ} \mathrm{S}$ (Fig. 4f). SP was lower $(-10 \%$ to $0 \%$ ) at the surface $(<10 \mathrm{~m})$ near $9^{\circ} \mathrm{S}$ and at $50-150 \mathrm{~m}$ near $11^{\circ} \mathrm{S}$; higher SP $\left(10 \% \circ-20 \%\right.$ ) was observed south of $14^{\circ} \mathrm{S}$ (Fig. $4 \mathrm{~g}$ ). The $\delta^{18} \mathrm{O}$ values were $45 \%$ - $60 \%$; higher $\delta^{18} \mathrm{O}(>55 \%$ ) values were observed within the ODZ below $200 \mathrm{~m}$ at $14{ }^{\circ} \mathrm{S}$ and below $100 \mathrm{~m}$ at $15.3^{\circ} \mathrm{S}$ (Fig. $4 \mathrm{~h}$ ).

\subsection{Excess $\mathrm{N}_{2} \mathrm{O}$ and $\mathrm{N}_{2} \mathrm{O}$ flux to the atmosphere}

Both the offshore and coastal stations showed $\mathrm{N}_{2} \mathrm{O}$ supersaturation in the top $10 \mathrm{~m}$ of surface water, and coastal stations had higher $\Delta \mathrm{N}_{2} \mathrm{O}$ concentrations $\left(15-50 \mathrm{nmol} \mathrm{L}^{-1}\right)$ than those of offshore stations $\left(4-8 \mathrm{nmol} \mathrm{L}^{-1}\right)$. Subsurface $\Delta \mathrm{N}_{2} \mathrm{O}$ along the offshore section had higher concentrations at the equatorial regions $\left(70-80 \mathrm{nmol} \mathrm{L}^{-1}\right)$ than $\Delta \mathrm{N}_{2} \mathrm{O}$ concentrations at stations located south of $10^{\circ} \mathrm{S}\left(40-60 \mathrm{nmol} \mathrm{L}^{-1}\right.$, Fig. 5a). Near $15^{\circ} \mathrm{S}$, subsurface $\mathrm{N}_{2} \mathrm{O}$ undersaturation was observed; $\Delta \mathrm{N}_{2} \mathrm{O}$ concentrations were -4 to $0 \mathrm{nmol} \mathrm{L}^{-1}$ at thermocline depths $(200-400 \mathrm{~m})$ within the ODZ $\left(\left[\mathrm{O}_{2}\right]<\right.$ $5 \mu \mathrm{mol} \mathrm{L}^{-1}$ ). Along the coastal section, a southward increase in surface and subsurface $(50-200 \mathrm{~m}) \Delta \mathrm{N}_{2} \mathrm{O}$ was observed (Fig. 5b). Subsurface maximum $\Delta \mathrm{N}_{2} \mathrm{O}$ concentrations were $>60 \mathrm{nmol} \mathrm{L}^{-1}$, and occurred at the periphery of ODZ $(\sim$ $200 \mathrm{~m}$ near $10^{\circ} \mathrm{S}$ and $<100 \mathrm{~m}$ south of $12^{\circ} \mathrm{S}$ ). Undersat- 
Offshore

(a)

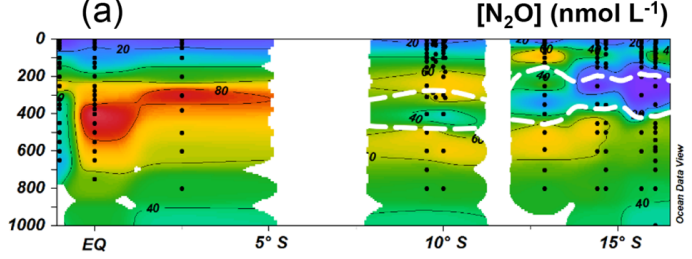

(b)

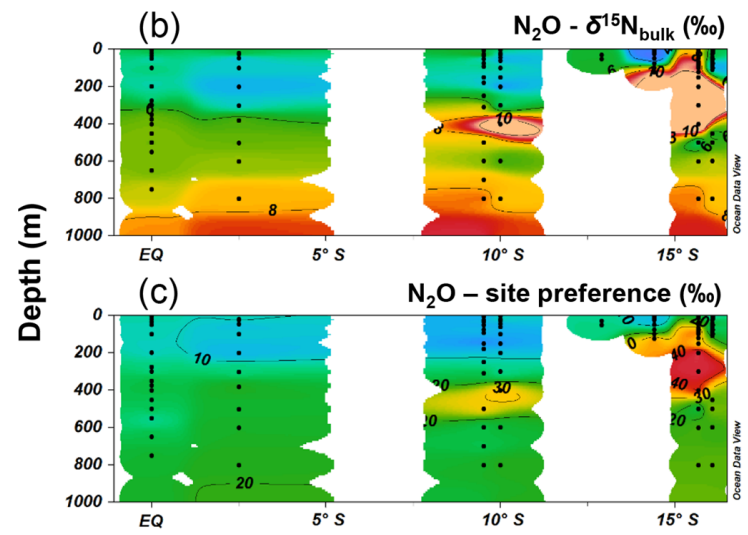

(d)

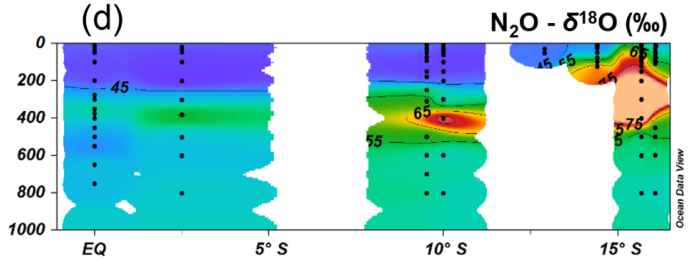

Coastal

(e)

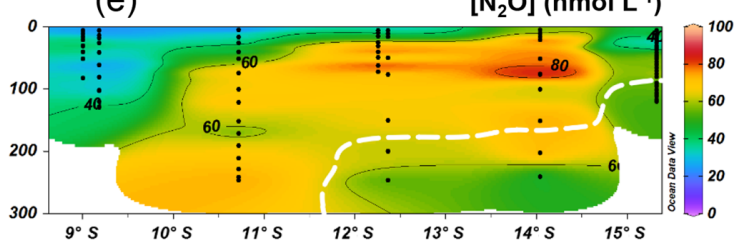

(f)

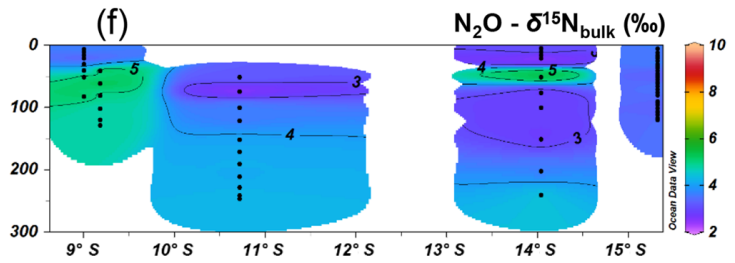

(g)

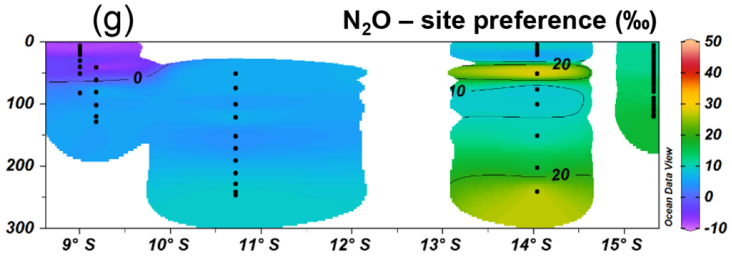

(h)

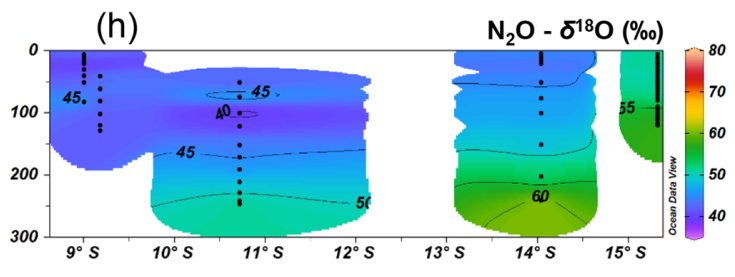

Latitude

Figure 4. Water column $\mathrm{N}_{2} \mathrm{O}$ concentrations (a, e), $\delta^{15} \mathrm{~N}_{\text {bulk }}(\mathbf{b}, \mathbf{f})$, site preference $(\mathbf{c}, \mathbf{g})$, and $\delta^{18} \mathrm{O}(\mathbf{d}, \mathbf{h})$ along the offshore (a, b, $\left.\mathbf{c}, \mathbf{d}\right)$ and coastal sections (e, f, g, h) during October 2015. White contour lines in (a) and (e) denote the boundary of the oxygen-deficient zone $\left(\left[\mathrm{O}_{2}\right]=5 \mu \mathrm{mol} \mathrm{L}^{-1}\right.$ isoline $)$.

uration of $\mathrm{N}_{2} \mathrm{O}\left(\Delta \mathrm{N}_{2} \mathrm{O}<0\right)$ did not occur in any coastal stations. The $\mathrm{N}_{2} \mathrm{O}$ fluxes from the coastal stations were 23-108 $\mu \mathrm{mol} \mathrm{m} \mathrm{m}^{-2} \mathrm{~d}^{-1}$, nearly 2-fold the offshore fluxes (7$50 \mu \mathrm{mol} \mathrm{m}{ }^{-2} \mathrm{~d}^{-1}$, Fig. 5c). The highest flux occurred at a coastal station at $14.4^{\circ} \mathrm{S}, 77.3^{\circ} \mathrm{W}$, coinciding with the highest surface $\Delta \mathrm{N}_{2} \mathrm{O}\left(50 \mathrm{nmol} \mathrm{L}^{-1}\right)$.

\section{Discussion}

The ETSP is one of the world's major oceanic OMZs having active $\mathrm{N}_{2} \mathrm{O}$ production and intense efflux to the atmosphere (Arévalo-Martínez et al., 2015; Kock et al., 2016). The gradient spanning from fully oxygenated conditions to anoxia creates suitable conditions for $\mathrm{N}_{2} \mathrm{O}$ production and consumption, which causes the coexistence of water column $\mathrm{N}_{2} \mathrm{O}$ supersaturation and undersaturation (Codispoti and Christensen, 1985). To identify the $\mathrm{N}_{2} \mathrm{O}$ cycling pathways, we input $\mathrm{N}_{2} \mathrm{O}$ isotopic and isotopomeric measurements into a simple mass balance model (Sect. 4.1). Quantitative relationships linking $\mathrm{O}_{2}, \mathrm{NO}_{3}^{-}$, and $\mathrm{N}_{2} \mathrm{O}$ were examined to char- acterize the effect of oxygenation on $\mathrm{N}_{2} \mathrm{O}$ production from $\mathrm{NH}_{4}^{+}$oxidation (Sect. 4.2). Previously measured $\mathrm{N}_{2} \mathrm{O}$ concentrations from the ETSP were extracted from the MEMENTO database (Kock and Bange, 2015) and were compared to data from this study to investigate the contrasting water column $\mathrm{N}_{2} \mathrm{O}$ distribution and effluxes between El Niño and non-El Niño years (Sect. 4.3), which would better constrain the natural variability of $\mathrm{N}_{2} \mathrm{O}$ cycling in the ETSP.

\section{1 $\mathrm{N}_{2} \mathrm{O}$ cycling pathways inferred from natural abundance isotopic and isotopomeric signatures}

The analyses of natural abundance isotopomers quantify the substitutions of nitrogen and oxygen isotopes occurring on the linear asymmetric $\mathrm{N}_{2} \mathrm{O}$ molecule (Yoshida and Toyoda, 2000), and can be used to identify potential production and consumption pathways (Yamagishi et al., 2007; Grundle et al., 2017). The production of $\mathrm{N}_{2} \mathrm{O}$ in an isolated water body follows mass conservation of the respective isotopes and isotopomers. The mass balance model proposed by Fujii et al. (2013) quantified the isotopic signature of $\mathrm{N}_{2} \mathrm{O}$ produced 

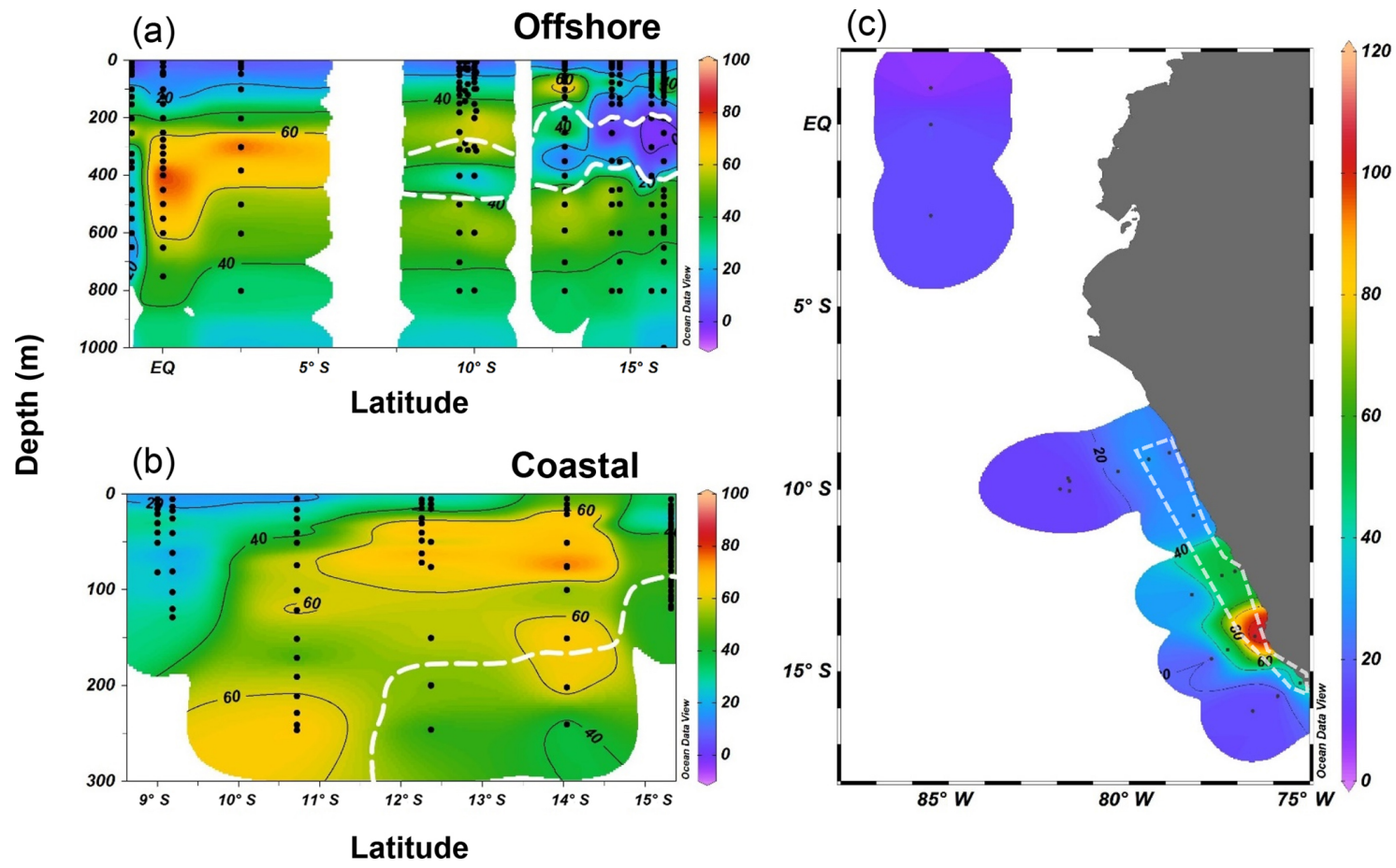

Figure 5. $\mathrm{N}_{2} \mathrm{O}$ excess $\left(\Delta \mathrm{N}_{2} \mathrm{O}\right.$, nmol L $\left.{ }^{-1}\right)$ at the offshore section (a) and the coastal section (b) during October 2015; the white dashed line indicates the boundary of the oxygen-deficient zone $\left(\left[\mathrm{O}_{2}\right]=5 \mu \mathrm{mol} \mathrm{L}-1\right.$ isoline). (c) Surface $\mathrm{N}_{2} \mathrm{O}$ efflux $\left(\mu \mathrm{mol} \mathrm{m}{ }^{-2} \mathrm{~d}^{-1}\right)$ from offshore and coastal stations (enclosed in white polygon) during October 2015.

within the water mass $\left(\delta_{\text {produced }}\right)$ by the linear regression of the inverse $\mathrm{N}_{2} \mathrm{O}$ concentration $\left(1 /\left[\mathrm{N}_{2} \mathrm{O}\right]_{\text {measured }}\right)$ and the observed isotope values $\left(\delta_{\text {observed }}\right)$ :

$$
\begin{aligned}
\delta_{\text {observed }} & =\frac{\left[\mathrm{N}_{2} \mathrm{O}\right]_{\text {initial }}}{\left[\mathrm{N}_{2} \mathrm{O}\right]_{\text {measured }}} \times\left(\delta_{\text {initial }}-\delta_{\text {produced }}\right) \\
& +\delta_{\text {produced }},
\end{aligned}
$$

where $\left[\mathrm{N}_{2} \mathrm{O}\right]_{\text {initial }}$ and $\delta_{\text {initial }}$ refer to source water $\mathrm{N}_{2} \mathrm{O}$ concentration and isotopic signature, respectively. It has been shown that $\mathrm{SP}$ is only determined by $\mathrm{N}_{2} \mathrm{O}$ cycling pathways and that SP is independent of nitrogen isotopic values of the substrates for $\mathrm{N}_{2} \mathrm{O}$ cycling. Both culture and field studies demonstrated that $\mathrm{N}_{2} \mathrm{O}$ production via $\mathrm{NH}_{4}^{+}$oxidation and partial denitrification (including both nitrifier- and denitrifier-mediated denitrification) are associated with typical SP values of $30 \pm 5 \%$ and $0 \pm 5 \%$ o, respectively (Toyoda et al., 2011). Recent results from culture (Winther et al., 2018) and river water (Mothet et al., 2013) showed that $\mathrm{N}_{2} \mathrm{O}$ production via denitrification had SP values as low as $-10 \%$. Thus, by determining $\mathrm{SP}_{\text {produced }}, \mathrm{N}_{2} \mathrm{O}$ cycling processes can be qualitatively characterized. We further identified four water bodies (coastal and offshore stations combined) from shallow to deeper depths with distinctive features such as $\mathrm{O}_{2}, \mathrm{NO}_{2}^{-}$concentrations, and depths (Table 1) to discuss $\mathrm{N}_{2} \mathrm{O}$ cycling pathways as follows.

1. Upper oxycline and surface (Fig. S1a in the Supplement): $\left[\mathrm{O}_{2}\right]>20 \mu \mathrm{mol} \mathrm{L}^{-1},\left[\mathrm{NO}_{2}^{-}\right]<1 \mu \mathrm{mol} \mathrm{L}^{-1}$, and depth $<200 \mathrm{~m} . \mathrm{N}_{2} \mathrm{O}$ production from this water body could actively contribute to atmospheric efflux. The samples had variable SP values ( $-9 \%$ o to $34 \%$ ); some coastal samples had low SP values ( $-5 \%$ to $-9 \%$, Fig. 4g), which as outlined above is characteristic of strong denitrifying $\mathrm{N}_{2} \mathrm{O}$ production. The low $\mathrm{SP}_{\text {produced }}$ $(6.4 \pm 1.9)$ indicates that both nitrification and denitrification were sources of $\mathrm{N}_{2} \mathrm{O}$ to the upper oxycline, with the majority appearing to come from denitrification. Given that the $\mathrm{O}_{2}$ concentrations were too high for denitrification to proceed locally in the upper oxycline and the surface (Codispoti and Christensen, 1985), the SP signature of $\mathrm{N}_{2} \mathrm{O}$ in this water body was a mixture of local nitrification and denitrification signal from the peak $\mathrm{N}_{2} \mathrm{O}$ concentration depths (see below) as a result of active upwelling and upward diffusion in the ETSP (Haskell et al., 2015). Thus, denitrification and nitrification both contribute to $\mathrm{N}_{2} \mathrm{O}$ effluxes in the ETSP OMZ, consistent with a previous study which focused on the coastal regions between $\sim 12$ and $14^{\circ} \mathrm{S}$ (Bourbonnais et al., 2017).

2. $\mathrm{N}_{2} \mathrm{O}$ peak (Fig. S1b): $\left[\mathrm{O}_{2}\right]=5-20 \mu \mathrm{mol} \mathrm{L}^{-1},\left[\mathrm{NO}_{2}^{-}\right]<$ $1 \mu \mathrm{mol} \mathrm{L}^{-1}$, and depth $=45-500 \mathrm{~m}$. The samples were from $\mathrm{N}_{2} \mathrm{O}$ concentration maxima near the upper boundary of the ODZ. The $\mathrm{SP}_{\text {produced }}$ is relatively low $(8.3 \pm 3.0 \%)$ at this suboxic water body $\left(\left[\mathrm{O}_{2}\right]<\right.$ $20 \mu \mathrm{mol} \mathrm{L}^{-1}$ ), which allowed $\mathrm{N}_{2} \mathrm{O}$ production from 
denitrification while inhibiting $\mathrm{N}_{2} \mathrm{O}$ consumption (Bonin et al., 1989; Farías et al., 2009). The $\mathrm{SP}_{\text {produced }}$ leads us to conclude that water column $\mathrm{N}_{2} \mathrm{O}$ maximum was mainly attributed to partial denitrification (i.e., $\mathrm{NO}_{2}^{-}$and $\mathrm{NO}_{3}^{-}$reduction). This is consistent with previous ${ }^{15} \mathrm{~N}$ tracer incubation experiments demonstrating that $\mathrm{N}_{2} \mathrm{O}$ concentration maximum above the ODZ was likely the result of high rates of $\mathrm{N}_{2} \mathrm{O}$ production from $\mathrm{NO}_{2}^{-}$and $\mathrm{NO}_{3}^{-}$reduction that are 10-100 times higher than the rate of $\mathrm{NH}_{4}^{+}$oxidation to $\mathrm{N}_{2} \mathrm{O}$ ( $\mathrm{Ji}$ et al., 2015).

3. Oxygen-deficient zone (Fig. S1c): $\left[\mathrm{O}_{2}\right]<5 \mu \mathrm{mol} \mathrm{L}-1$ and $\left[\mathrm{NO}_{2}^{-}\right]>1 \mu \mathrm{mol} \mathrm{L}{ }^{-1}$, and depth $=70-400 \mathrm{~m}$. The ODZ has prominent features such as the accumulation of $\mathrm{NO}_{2}^{-}$(Codispoti and Christensen, 1985), and undersaturation of $\mathrm{N}_{2} \mathrm{O}$ as a result of dynamic balance between the concomitant $\mathrm{N}_{2} \mathrm{O}$ production ( $\mathrm{Ji}$ et al., 2015) and consumption by denitrification (Babbin et al., 2015). The isotopic signature of "produced $\mathrm{N}_{2} \mathrm{O}$ " had distinctively high $\delta^{15} \mathrm{~N}_{\text {bulk }}\left(8.5 \%\right.$ ) and $\delta^{18} \mathrm{O}(71 \%$, Table 1 and Fig. S2), and this is indicative of pronounced $\mathrm{N}_{2} \mathrm{O}$ reduction to $\mathrm{N}_{2}$, which results in an isotope enrichment of the remaining $\mathrm{N}_{2} \mathrm{O}$ pool in the process of $\mathrm{N}-\mathrm{O}$ bond breakage (Toyoda et al., 2017). The SP signature was also high $\left(39.9 \%\right.$ ). While $\mathrm{NH}_{4}^{+}$oxidation can produce $\mathrm{N}_{2} \mathrm{O}$ with similar SP values, we rule this out given the observed low $\mathrm{O}_{2}$ concentrations (Peng et al., 2016). Instead, similar to the high $\delta^{15} \mathrm{~N}_{\text {bulk }}$ and $\delta^{18} \mathrm{O}$ values which were observed, we suggest that the high SP values which were recorded in the ODZ, where $\mathrm{N}_{2} \mathrm{O}$ undersaturation occurred, were also a result of $\mathrm{N}_{2} \mathrm{O}$ consumption, as reduction of $\mathrm{N}_{2} \mathrm{O}$ can also result in high SP values (Popp et al., 2002; Well et al., 2005; Mothet et al., 2013). Based on the observed $\delta^{15} \mathrm{~N}_{\text {bulk }}, \delta^{18} \mathrm{O}$, and $\mathrm{SP}$ values of $\mathrm{N}_{2} \mathrm{O}$, we conclude that $\mathrm{N}_{2} \mathrm{O}$ consumption was the predominant $\mathrm{N}_{2} \mathrm{O}$ cycling pathway in the water body with $\left[\mathrm{O}_{2}\right]<5 \mu \mathrm{mol} \mathrm{L}{ }^{-1}$ and $\left[\mathrm{NO}_{2}^{-}\right]>1 \mu \mathrm{mol} \mathrm{L}^{-1}$ in the ETSP.

4. Intermediate waters (Fig. S1d): samples from depths $500-1000 \mathrm{~m}$ with $\left[\mathrm{O}_{2}\right]=5-70 \mu \mathrm{mol} \mathrm{L}^{-1}$ and $\left[\mathrm{NO}_{2}^{-}\right]<1 \mu \mathrm{mol} \mathrm{L}{ }^{-1}$. Generally, the $\mathrm{N}_{2} \mathrm{O}$ concentration peak below the ODZ at the offshore waters can be found in this water body (Fig. 4a). From the linear regression, the $\mathrm{SP}_{\text {produced }}$ is $15.6 \pm 4.1 \%$, indicating that both nitrification and denitrification produced $\mathrm{N}_{2} \mathrm{O}$ under the oxic and suboxic conditions $\left(\left[\mathrm{O}_{2}\right]=5-\right.$ $\left.70 \mu \mathrm{mol} \mathrm{L}^{-1}\right)$. Downward mixing and diffusion from the ODZ is unlikely because the ETSP is a major upwelling region and ODZ samples had high SP values (see next paragraph). We conclude that localized $\mathrm{N}_{2} \mathrm{O}$ production from nitrification and denitrification is an important pathway in this region of the water column, and probably contributed to $\mathrm{N}_{2} \mathrm{O}$ concentration maxima in intermediate waters, as reported by Carrasco et al. (2017).

There are some limitations of the isotopomer-based analysis of potential $\mathrm{N}_{2} \mathrm{O}$ cycling pathways. (1) Constant atmospheric exchange at the surface and mixed layer, and mesoscale eddy activities at intermediate waters (ArévaloMartínez et al., 2016) could affect the $\mathrm{SP}_{\text {produced }}$ from localized $\mathrm{N}_{2} \mathrm{O}$ cycling. Nevertheless, our conclusion of denitrification being an important pathway remains valid. As a comparison, water bodies were divided by potential density surfaces (i.e., $\sigma_{\theta}>27,26-27,25-26,<25 \mathrm{~kg} \mathrm{~m}^{-3}$ ) and showing $\mathrm{SP}_{\text {produced }}$ of 5.0\%o-11.1\%o. (2) We are not able to investigate the change in $\mathrm{N}_{2} \mathrm{O}$ production rates from nitrification and denitrification that are affected by El Niño-induced lower export production, as demonstrated by Espinoza-Morriberón et al. (2017). With complimentary datasets such as isotopic compositions of $\mathrm{NO}_{3}^{-}$and $\mathrm{NO}_{2}^{-}$, the rates of $\mathrm{N}_{2} \mathrm{O}$ production can be derived by isotopic relationships during $\mathrm{N}_{2} \mathrm{O}$ production processes using a three-dimensional biogeochemical model (Bourbonnais et al., 2017).

\subsection{The effect of $\mathrm{O}_{2}$ on $\mathrm{N}_{2} \mathrm{O}$ production from $\mathrm{NH}_{4}^{+}$ oxidation}

The surface and upper oxycline directly contribute to oceanic $\mathrm{N}_{2} \mathrm{O}$ effluxes, with $\mathrm{NH}_{4}^{+}$oxidation being the dominant production pathway due to $\mathrm{O}_{2}$ inhibition of denitrification (see Sect. 4.1). Thus, it is worth investigating $\mathrm{N}_{2} \mathrm{O}$ production from $\mathrm{NH}_{4}^{+}$oxidation occurring along the oxygen gradient. During $\mathrm{NH}_{4}^{+}$oxidation to $\mathrm{NO}_{2}^{-}$, the effectiveness of $\mathrm{N}_{2} \mathrm{O}$ production can be quantified with the $\mathrm{N}_{2} \mathrm{O}$ yield, which is defined as the molar nitrogen ratio of $\mathrm{N}_{2} \mathrm{O}$ produced and $\mathrm{NH}_{4}^{+}$oxidized. In oxygenated waters, the near absence of $\mathrm{NH}_{4}^{+}$and $\mathrm{NO}_{2}^{-}$suggests the amount of $\mathrm{NH}_{4}^{+}$oxidized produces equal amounts of $\mathrm{NO}_{3}^{-}$within measurement error. Rees et al. (2011) and Grundle et al. (2012) computed the $\mathrm{N}_{2} \mathrm{O}$ yield by deriving the slope of the linear regression of the $\Delta \mathrm{N}_{2} \mathrm{O}-\mathrm{NO}_{3}^{-}$relationship. The $\Delta \mathrm{N}_{2} \mathrm{O}$ data from all sampling stations during October 2015 showed that $\Delta \mathrm{N}_{2} \mathrm{O}$ increases with increasing $\mathrm{NO}_{3}^{-}$concentrations and decreasing $\mathrm{O}_{2}$ concentrations (Fig. 6). The samples from the upper oxycline $\left(\left[\mathrm{O}_{2}\right]>20 \mu \mathrm{mol} \mathrm{L}{ }^{-1}\right.$ and depth $\left.>500 \mathrm{~m}\right)$ showed a moderate increase in $\Delta \mathrm{N}_{2} \mathrm{O}\left(0-20 \mathrm{nmol} \mathrm{L}^{-1}\right)$ when $\left[\mathrm{NO}_{3}^{-}\right]<20 \mu \mathrm{mol} \mathrm{L}{ }^{-1}$. At $\left[\mathrm{NO}_{3}^{-}\right]>20 \mu \mathrm{mol} \mathrm{L}{ }^{-1}$, substantial increase in $\Delta \mathrm{N}_{2} \mathrm{O}\left(20-75 \mathrm{nmol} \mathrm{L}^{-1}\right)$ was observed. Here, to avoid sampling the ODZ where suboxic conditions stimulate $\mathrm{N}_{2} \mathrm{O}$ production from partial denitrification (i.e., water body no. 3 described in Sect. 4.1), only data from the upper oxycline (depth $<500 \mathrm{~m}$ ) were used to perform linear regression. The slope of the regression at $\left[\mathrm{NO}_{3}^{-}\right]<20 \mu \mathrm{mol} \mathrm{L}{ }^{-1}$ (corresponding to $\left[\mathrm{O}_{2}\right]>100 \mu \mathrm{mol} \mathrm{L} \mathrm{L}^{-1}$ ) is $0.85 \pm 0.11$, indicating that $0.085 \pm 0.011 \mathrm{nmol}$ of $\mathrm{N}_{2} \mathrm{O}$ is produced for every micromole of $\mathrm{NO}_{3}^{-}$produced (or $\mathrm{NH}_{4}^{+}$oxidized), equating a molar nitrogen yield $\left(\mathrm{mol} \mathrm{N}_{2} \mathrm{O}-\mathrm{N}\right.$ produced $/ \mathrm{mol} \mathrm{NO} \mathrm{N}_{3}^{-}$ 
Table 1. Isotopic signature of $\mathrm{N}_{2} \mathrm{O}$ cycling processes estimated by linear regression of isotopomer ratios and inverse $\mathrm{N}_{2} \mathrm{O}$ concentrations (see Sect. 4.1 for model description and Fig. $\mathrm{S} 1$ for results) in water bodies of upper oxycline and surface, $\mathrm{N}_{2} \mathrm{O}$ peak, oxygen-deficient zone, and intermediate waters.

\begin{tabular}{|c|c|c|c|c|c|c|}
\hline No. & Layer & Definition & Statistical properties & $\delta^{15} \mathrm{~N}_{\text {bulk }}(\% o)$ & $\delta^{18} \mathrm{O}(\% \circ)$ & $\mathrm{SP}(\% \circ)$ \\
\hline \multirow[t]{3}{*}{1} & \multirow{3}{*}{$\begin{array}{l}\text { Upper oxycline } \\
\text { and surface }\end{array}$} & \multirow{3}{*}{$\begin{array}{l}\text { Depth } 0-200 \mathrm{~m} \\
{\left[\mathrm{O}_{2}\right]>5 \mu \mathrm{mol} \mathrm{L}} \\
{\left[\mathrm{NO}_{2}^{-}\right]<1 \mu \mathrm{mol} \mathrm{L}^{-1}}\end{array}$} & Produced $\mathrm{N}_{2} \mathrm{O}$ & 2.8 & 45.9 & 6.4 \\
\hline & & & Standard error & 0.3 & 1.2 & 1.9 \\
\hline & & & $R^{2}(n=76)$ & 0.37 & 0 & 0.04 \\
\hline \multirow[t]{3}{*}{2} & \multirow[t]{3}{*}{$\mathrm{N}_{2} \mathrm{O}$ peak } & \multirow{3}{*}{$\begin{array}{l}\text { Depth }=45-500 \mathrm{~m} \\
{\left[\mathrm{O}_{2}\right]=5-20 \mu \mathrm{mol} \mathrm{L}} \\
{\left[\mathrm{NO}_{2}^{-}\right]<1 \mu \mathrm{mol} \mathrm{L}} \\
\end{array}$} & Produced $\mathrm{N}_{2} \mathrm{O}$ & 5.4 & 41.3 & 8.3 \\
\hline & & & Standard error & 0.9 & 3.0 & 3.0 \\
\hline & & & $R^{2}(n=48)$ & 0.04 & 0.24 & 0.08 \\
\hline \multirow[t]{3}{*}{3} & \multirow[t]{3}{*}{ Oxygen-deficient zone } & \multirow{3}{*}{$\begin{array}{l}\text { Depth }=70-400 \mathrm{~m} \\
{\left[\mathrm{O}_{2}\right]<5 \mu \mathrm{mol} \mathrm{L}-1} \\
{\left[\mathrm{NO}_{2}^{-}\right]>1 \mu \mathrm{mol} \mathrm{L}}\end{array}$} & Produced $\mathrm{N}_{2} \mathrm{O}$ & 8.5 & 71.0 & 39.9 \\
\hline & & & Standard error & 1.5 & 4.5 & 4.4 \\
\hline & & & $R^{2}(n=11)$ & 0.38 & 0.40 & 0.01 \\
\hline \multirow[t]{3}{*}{4} & \multirow[t]{3}{*}{ Intermediate waters } & \multirow{3}{*}{$\begin{array}{l}\text { Depth }=500-1000 \mathrm{~m} \\
{\left[\mathrm{O}_{2}\right]=5-70 \mu \mathrm{mol} \mathrm{L}^{-1}} \\
{\left[\mathrm{NO}_{2}^{-}\right]<0.02 \mu \mathrm{mol} \mathrm{L}^{-1}}\end{array}$} & Produced $\mathrm{N}_{2} \mathrm{O}$ & 3.6 & 50.0 & 15.6 \\
\hline & & & Standard error & 0.6 & 2.4 & 4.1 \\
\hline & & & $R^{2}(n=21)$ & 0.69 & 0 & 0.04 \\
\hline
\end{tabular}

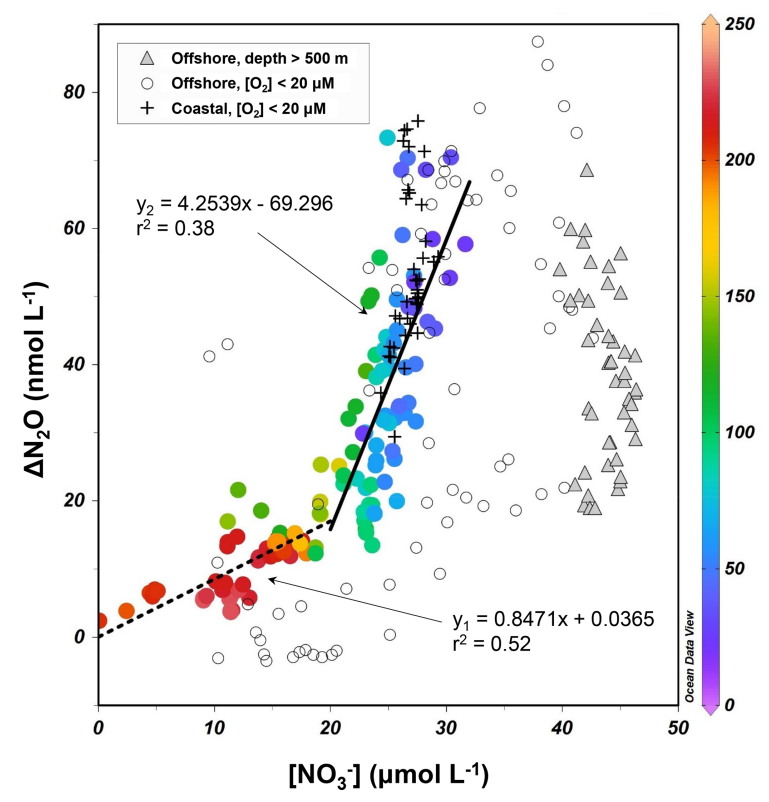

Figure 6. $\mathrm{NO}_{3}^{-}-\Delta \mathrm{N}_{2} \mathrm{O}$ relationship for samples from the upper oxycline $\left(\left[\mathrm{O}_{2}\right]>20 \mu \mathrm{mol} \mathrm{L}^{-1}\right.$, depth $<500 \mathrm{~m}$, colored circles $)$, low-oxygen $\left(\left[\mathrm{O}_{2}\right]<20 \mu \mathrm{mol} \mathrm{L}{ }^{-1}\right)$ coastal waters $(+)$, low-oxygen offshore waters (open circles), and the lower oxycline (depth $>$ $500 \mathrm{~m}$, filled triangles). Color bar shows the $\mathrm{O}_{2}$ concentrations $(\mu \mathrm{mol} \mathrm{L}-1)$. For samples with $\mathrm{NO}_{3}^{-}$concentrations higher and lower than $20 \mu \mathrm{mol} \mathrm{L}^{-1}$, two linear regressions were performed separately.

produced) of $0.17 \pm 0.02 \%$. At $\left[\mathrm{NO}_{3}^{-}\right]>20 \mu \mathrm{mol} \mathrm{L}^{-1}$ (corresponding to $\left[\mathrm{O}_{2}\right]<100 \mu \mathrm{mol} \mathrm{L}^{-1}$ ) the yield increases to $0.85 \pm 0.13 \%$.

These $\mathrm{N}_{2} \mathrm{O}$ yield estimates are generally comparable to previously reported values $(0.04 \%-1.6 \%)$ in the ETSP
(Elkins et al., 1978; Ji et al., 2015), and indicate that potential $\mathrm{N}_{2} \mathrm{O}$ production from $\mathrm{NH}_{4}^{+}$oxidation decreases with water column oxygenation due to intrusion of oxygen-rich water masses (Llanillo et al., 2013; Graco et al., 2017), as well as El Niño-induced oxygenation (see Sect. 4.3). As discussed earlier, the oxycline samples were probably influenced by mixing of suboxic water with active denitrification, producing high $\mathrm{N}_{2} \mathrm{O}$ concentrations and low $\mathrm{NO}_{3}^{-}$concentrations; the $\mathrm{N}_{2} \mathrm{O}$ yield estimates here are thus spatially and temporally integrated. As a comparison, the ${ }^{15} \mathrm{~N}$ tracer incubation method directly measured $0.04 \% \mathrm{~N}_{2} \mathrm{O}$ yield during $\mathrm{NH}_{4}^{+}$oxidation at $\left[\mathrm{O}_{2}\right]>100 \mu \mathrm{mol} \mathrm{L}^{-1}$ (Ji et al., 2015).

\section{3 $\quad \mathrm{N}_{2} \mathrm{O}$ distribution and fluxes during El Niño}

Excess $\mathrm{N}_{2} \mathrm{O}\left(\Delta \mathrm{N}_{2} \mathrm{O}\right)$ in surface waters is one of the principal factors regulating sea-to-air $\mathrm{N}_{2} \mathrm{O}$ fluxes. To evaluate the effect of strong El Niño on oceanic $\mathrm{N}_{2} \mathrm{O}$ fluxes, we compare surface and water column $\Delta \mathrm{N}_{2} \mathrm{O}$ concentrations in shelf waters $\left(<300 \mathrm{~m}\right.$ depth) along $8-16^{\circ} \mathrm{S}$ during El Niño (October 2015) and neutral conditions (December 2012). In the ETSP, higher surface $\Delta \mathrm{N}_{2} \mathrm{O}$ concentrations and thus higher potential $\mathrm{N}_{2} \mathrm{O}$ efflux occurred at nearshore waters. Generally, the surface $\Delta \mathrm{N}_{2} \mathrm{O}$ concentrations in October 2015 (Fig. 7a) were lower than those of December 2012 (Fig. 7d); the highest surface $\Delta \mathrm{N}_{2} \mathrm{O}$ concentrations were 50 and $250 \mathrm{nmol} \mathrm{L}^{-1}$ in 2015 and 2012 , respectively. The region of high surface $\Delta \mathrm{N}_{2} \mathrm{O}$ occurred near $\sim 14$ and $\sim 10^{\circ} \mathrm{S}$ in 2015 and in 2012, respectively. It appears that $\mathrm{N}_{2} \mathrm{O}$ efflux was significantly reduced during El Niño; in October 2015, coastal water had a $\mathrm{N}_{2} \mathrm{O}$ flux of 23 $108 \mu \mathrm{mol} \mathrm{m}^{-2} \mathrm{~d}^{-1}$ (Fig. 5c), much lower than that of December 2012 having $459-1825 \mu \mathrm{mol} \mathrm{m}^{-2} \mathrm{~d}^{-1}$ (Arévalo-Martínez et al., 2015). Such a $75 \%-95 \%$ reduction in $\mathrm{N}_{2} \mathrm{O}$ fluxes dur- 
October 2015

(a)

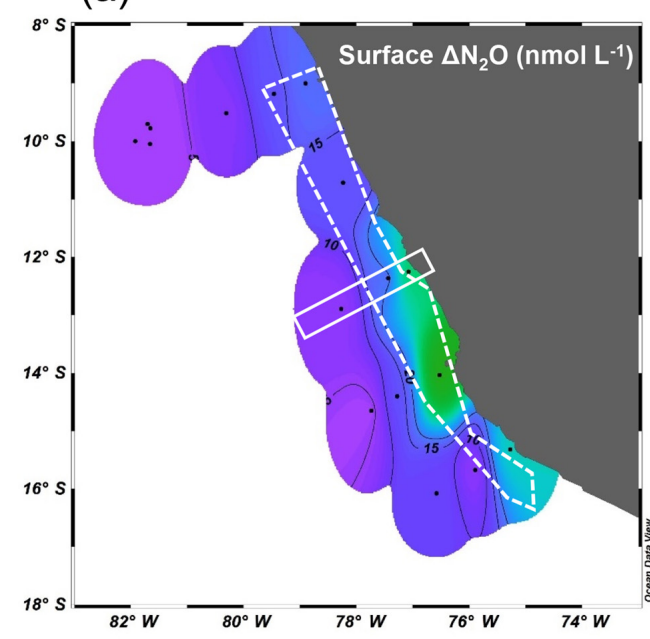

(b)

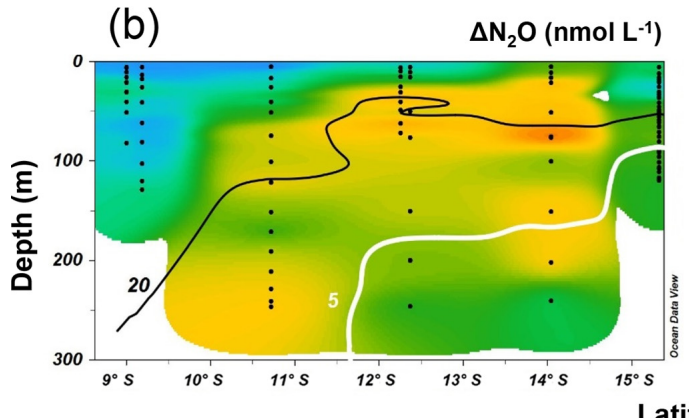

Latitude

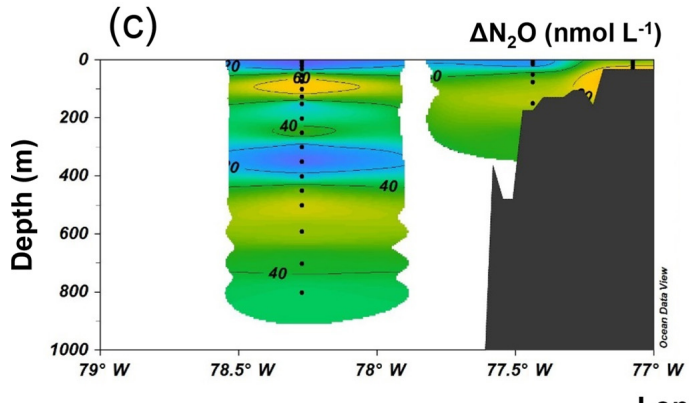

(f)

(d)

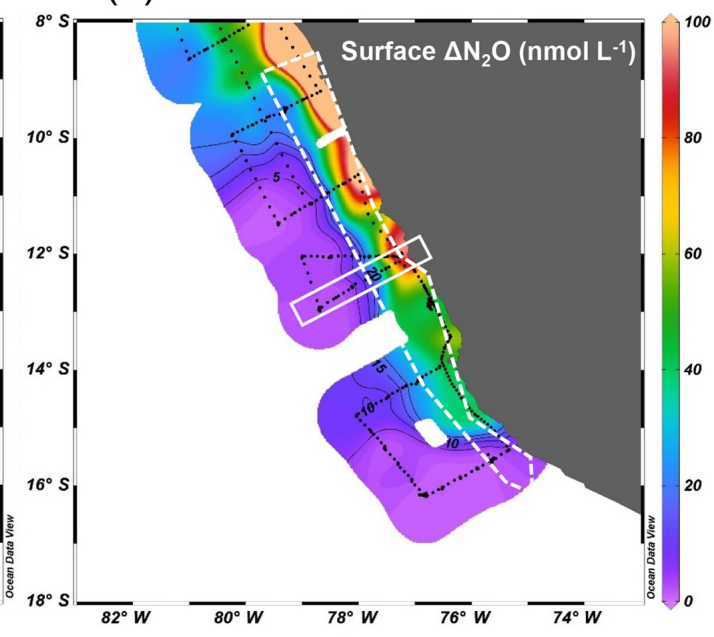

(e)

$\Delta \mathrm{N}_{2} \mathrm{O}\left(\mathrm{nmol} \mathrm{L}^{-1}\right)$

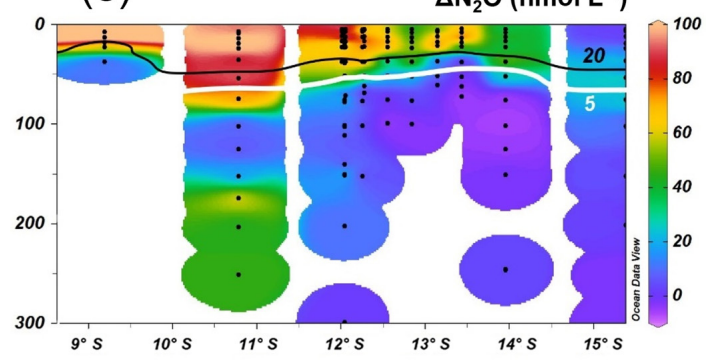

$\Delta \mathrm{N}_{2} \mathrm{O}(\mathrm{nmol} \mathrm{L-1})$

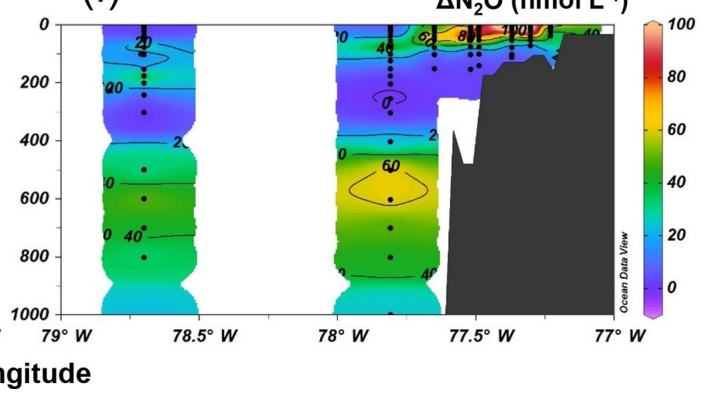

Figure 7. Surface $\Delta \mathrm{N}_{2} \mathrm{O}$ (a, d), meridional water column $\Delta \mathrm{N}_{2} \mathrm{O}$ distribution (b, e), and zonal water column $\Delta \mathrm{N}_{2} \mathrm{O}$ distribution (c, f) in October 2015 and in December 2012. Color bars for $\Delta \mathrm{N}_{2} \mathrm{O}\left(\mathrm{nmol} \mathrm{L}^{-1}\right)$ are shown in (d), (e), and (f). For meridional $\Delta \mathrm{N}_{2} \mathrm{O}$ distribution (b, e), data are from the coastal section, shown as a white dashed polygon in panels (a) and (d). For zonal $\Delta \mathrm{N}_{2} \mathrm{O}$ distribution (c, f), data are from a section $12-13^{\circ} \mathrm{S}$, shown as a white rectangle. In (b) and (e) the " 20 " contour line (black) denotes the $\left[\mathrm{O}_{2}\right]=20 \mu \mathrm{mol} \mathrm{L}-1$ isoline, equivalent to the lower boundary of the oxygenated layer; the " 5 " contour line (white) denotes the $\left[\mathrm{O}_{2}\right]=5 \mu \mathrm{mol} \mathrm{L}{ }^{-1}$ isoline, equivalent to the upper boundary of the oxygen-deficient zone.

ing the 2015-2016 El Niño in the ETSP was comparable to an $80 \%$ reduction in fluxes observed in the central equatorial Pacific during the 1982-1983 El Niño (Cline et al., 1987).

Suppressed upwelling or increased downwelling during El Niño events, as observed in both observational and model studies (Llanillo et al., 2013; Graco et al., 2017; Mogollón and Calil, 2017), can directly and indirectly affect $\mathrm{N}_{2} \mathrm{O}$ fluxes to the atmosphere: first, reduced upward transport of sub- surface $\mathrm{N}_{2} \mathrm{O}$-rich water not only decreased surface $\Delta \mathrm{N}_{2} \mathrm{O}$, but also increased subsurface $\Delta \mathrm{N}_{2} \mathrm{O}$, which is illustrated by the comparative observation of higher subsurface $\Delta \mathrm{N}_{2} \mathrm{O}$ concentrations in coastal waters in October 2015 (Fig. 7b, c) than those in December 2012 (Fig. 7e, f). Second, because the oxygen sensitivity of the denitrification sequence increases with each step (Körner and Zumft, 1989), El Niñoinduced water column oxygenation inhibited $\mathrm{N}_{2} \mathrm{O}$ consump- 


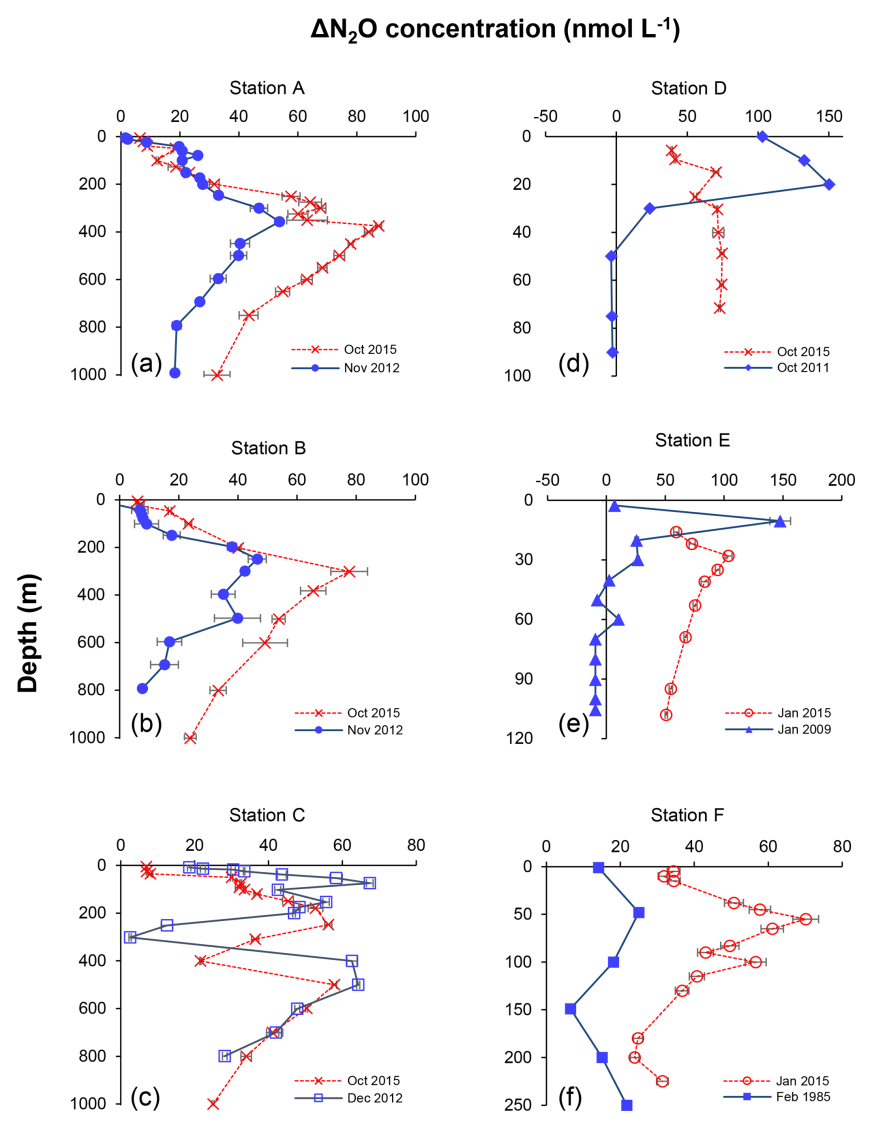

Figure 8. Depth profiles of $\mathrm{N}_{2} \mathrm{O}$ concentration excess $\left(\Delta \mathrm{N}_{2} \mathrm{O}\right.$, nmol $\left.\mathrm{L}^{-1}\right)$ measured at six different stations representing offshore $(\mathbf{a}, \mathbf{b}, \mathbf{c})$ and coastal waters $(\mathbf{d}, \mathbf{e}, \mathbf{f})$ during February 1985 (filled squares in f), January 2009 (filled triangles in e), October 2011 (filled diamonds in d), November 2012 (filled circles in a and b), December 2012 (open squares in c), January 2015 (open circles in e and f), and October 2015 (crosses). Profiles of 2015 are indicated in red and other years in blue. Error bars represent standard deviation of repeated measurements.

tion within the ODZ (bounded by $\left[\mathrm{O}_{2}\right]=5 \mu \mathrm{mol} \mathrm{L}^{-1}$ isoline), as demonstrated by the disappearance of $\mathrm{N}_{2} \mathrm{O}$ undersaturation $\left(\Delta \mathrm{N}_{2} \mathrm{O}<0\right)$ in coastal water in 2015 (Fig. 7b, c), contrasting water column $\mathrm{N}_{2} \mathrm{O}$ undersaturation occurring at $100 \mathrm{~m}$ at $13-14^{\circ} \mathrm{S}$ in December 2012 (Fig. 7e, f). Third, as shown in this study, the deepening and expansion of the suboxic zone $\left(\left[\mathrm{O}_{2}\right]=5-20 \mu \mathrm{mol} \mathrm{L}{ }^{-1}\right)$ caused by the El Niño event stimulated subsurface $\mathrm{N}_{2} \mathrm{O}$ production via denitrification, as demonstrated by the close spatial coupling between local maximum $\Delta \mathrm{N}_{2} \mathrm{O}$ concentrations and the oxycline $\left(\left[\mathrm{O}_{2}\right]=5\right.$ and $20 \mu \mathrm{mol} \mathrm{L}^{-1}$ isolines, Fig. $7 \mathrm{~b}$ and e). Lastly, upwelling of oxygen-rich water along the Peruvian coast, especially north of $12^{\circ} \mathrm{S}$ (Stramma et al., 2016), inhibited local $\mathrm{N}_{2} \mathrm{O}$ production and caused the southward relocation of surface $\Delta \mathrm{N}_{2} \mathrm{O}$ "hot spots".

The decrease in surface $\Delta \mathrm{N}_{2} \mathrm{O}$ concentration during $\mathrm{El}$ Niño was associated with an increase in subsurface $\mathrm{N}_{2} \mathrm{O}$ con-

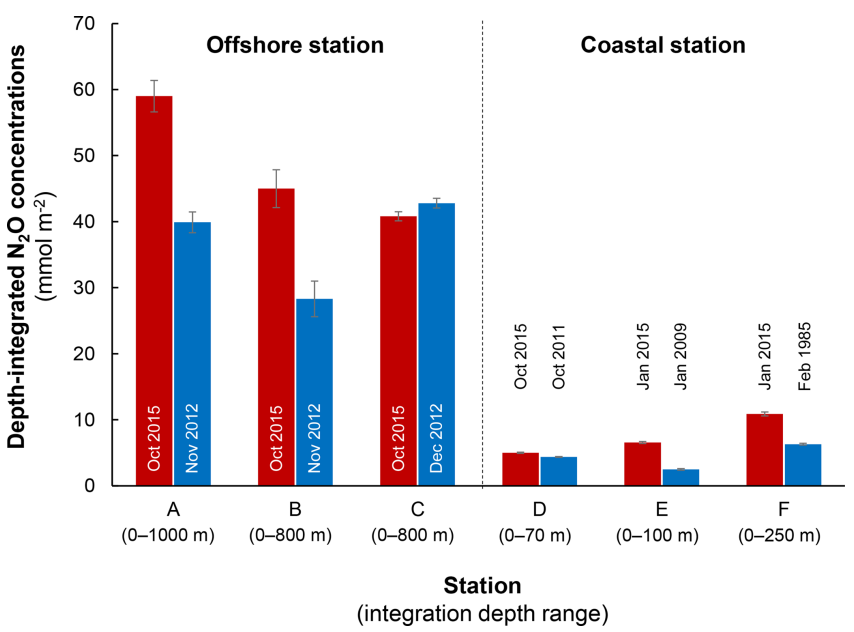

Figure 9. Comparison of depth-integrated $\mathrm{N}_{2} \mathrm{O}$ concentrations between El Niño (red bars) and normal years (blue bars). Stations A, $\mathrm{B}$, and $\mathrm{C}$ are characterized as offshore stations whereas $\mathrm{D}, \mathrm{E}$, and $\mathrm{F}$ are coastal stations. Error bars represent propagation of error from analytical precision of respective $\mathrm{N}_{2} \mathrm{O}$ concentration profiles. See Fig. 2a for station locations and Table S1 for data sources.

centrations. Water column $\Delta \mathrm{N}_{2} \mathrm{O}$ concentration profiles at expanded temporal and spatial coverage (see Fig. 2a for location map and Table S1 for coordinates) were compared within the same season between El Niño and non-El Niño years (Fig. 8). We included $\mathrm{N}_{2} \mathrm{O}$ data from January 2015 when the highest ONI was recorded during austral summer (Fig. 1). These comparisons at offshore stations were made to cover the depth ranges with pronounced El Niño effects and available data $(1000 \mathrm{~m}$ at station A and $800 \mathrm{~m}$ at stations B and C). At coastal stations the depth ranges were station bottom depth (stations D and E) or $250 \mathrm{~m}$ (station F). Generally, subsurface $\Delta \mathrm{N}_{2} \mathrm{O}$ concentration peaks were observed at deeper depths during 2015. Offshore stations had higher subsurface peak $\Delta \mathrm{N}_{2} \mathrm{O}$ concentrations during El Niño (Fig. 8a, b), except at station $\mathrm{C}$ where the peak concentration during October 2015 was comparable to that of December 2012 (Fig. 8c). At coastal stations $\mathrm{D}$ and $\mathrm{E}$, higher $\Delta \mathrm{N}_{2} \mathrm{O}$ concentrations were found below $50 \mathrm{~m}$ but peak $\Delta \mathrm{N}_{2} \mathrm{O}$ concentrations were lower during El Niño years (Fig. 8d, e). At the southernmost coastal station $\mathrm{F}$, the peak $\Delta \mathrm{N}_{2} \mathrm{O}$ concentration was higher in 2015 than that of 1985; both were found at similar depths at $\sim 60 \mathrm{~m}$. The increase in subsurface $\mathrm{N}_{2} \mathrm{O}$ concentrations during El Niño resulted in the OMZ water column retaining a larger amount of $\mathrm{N}_{2} \mathrm{O}$, as shown by higher depth-integrated $\mathrm{N}_{2} \mathrm{O}$ concentrations during El Niño years than non-El Niño years in both coastal and offshore waters (Fig. 9).

In all, the apparent decrease in $\mathrm{N}_{2} \mathrm{O}$ efflux during strong El Niño events in the tropical Pacific, as shown in this study and others (Cline et al., 1987; Butler et al., 1989) is the result of complex physical and biochemical changes. The above 
comparative analyses are simple due to limited data availability. Consequently, these following aspects are yet to be resolved: (1) it is unclear how offshore $\mathrm{N}_{2} \mathrm{O}$ fluxes vary from neutral to El Niño years. Current $\Delta \mathrm{N}_{2} \mathrm{O}$ profiles show higher surface $\Delta \mathrm{N}_{2} \mathrm{O}$ concentrations at stations $\mathrm{A}$ and $\mathrm{B}$ in 2015 (Fig. 8a and b), whereas the surface $\Delta \mathrm{N}_{2} \mathrm{O}$ was lower in 2015 at station $\mathrm{C}$ (Fig. 8c). A zonal (east-west) section near $12^{\circ} \mathrm{S}$ showed slightly higher offshore surface $\Delta \mathrm{N}_{2} \mathrm{O}$ in 2015 $\left(\sim 5 \mathrm{nmol} \mathrm{L}^{-1}\right.$, Fig. 7c) than in $2012\left(\sim 1 \mathrm{nmol} \mathrm{L}^{-1}\right.$, Fig. 7f $)$. The decrease in coastal $\mathrm{N}_{2} \mathrm{O}$ fluxes during El Niño could be compensated for by increase in offshore fluxes. (2) The southward relocation of high surface $\Delta \mathrm{N}_{2} \mathrm{O}$ from neutral to El Niño years (Fig. 7a and d) possibly results in higher surface $\Delta \mathrm{N}_{2} \mathrm{O}$ and hence higher $\mathrm{N}_{2} \mathrm{O}$ flux in the southern region of the ETSP (e.g., south of $16^{\circ} \mathrm{S}$; Fig. 8f). (3) Complex hydrographical changes during the El Niño event resulted in the deepening of the ODZ boundary and the depths of peak $\mathrm{N}_{2} \mathrm{O}$ concentration. It is possible that these chemical features occur in similar potential density surfaces (with respect to non-El Niño conditions) that are deepened during El Niño, or they occur in different potential density surfaces during El Niño, or a combination of both. (4) It is possible that once the normal upwelling is resumed after the El Niño event, $\mathrm{N}_{2} \mathrm{O}$ produced and retained in the subsurface layer in coastal and offshore waters could be a potential reservoir contributing to high $\mathrm{N}_{2} \mathrm{O}$ fluxes. (5) The co-occurrence of El Niño and mesoscale eddy formation along the Peruvian coast will have complicated effects on $\mathrm{N}_{2} \mathrm{O}$ fluxes, which remains unexplored.

\section{Conclusions}

The eastern tropical South Pacific is a major oceanic upwelling region with $\mathrm{N}_{2} \mathrm{O}$ effluxes and active water column production affected by strong El Niño events. During a developing strong El Niño event in October 2015, a more pronounced warming effect occurred at lower latitudes in the ETSP. In comparison to conditions in December 2012 (nonEl Niño), deepening of the oxygen-deficient zone's upper boundary occurred at coastal waters in October 2015, coinciding with lower peak $\mathrm{N}_{2} \mathrm{O}$ concentrations at deeper depths. Shelf $\mathrm{N}_{2} \mathrm{O}$ effluxes were significantly lower during the 2015 El Niño as a result of lower surface levels of $\mathrm{N}_{2} \mathrm{O}$ supersaturation. However, a change in upwelling pattern appeared to cause higher subsurface $\mathrm{N}_{2} \mathrm{O}$ concentrations and increased the water column $\mathrm{N}_{2} \mathrm{O}$ inventories during El Niño than in other non-El Niño years. Natural abundance isotopic and isotopomeric analysis indicated that both nitrification and denitrification are important pathways for $\mathrm{N}_{2} \mathrm{O}$ production, and denitrification-derived $\mathrm{N}_{2} \mathrm{O}$ near the suboxic waters probably contributes to the efflux to the atmosphere. Decreased $\mathrm{N}_{2} \mathrm{O}$ efflux and subsurface accumulation during strong El Niño events are likely the result of suppressed upwelling and a decrease in water column oxygen consumption. The current dataset represents a "snapshot" of a developing El Niño event that lasted 18 months; thus the complex spatial and temporal patterns of El Niño-induced $\mathrm{N}_{2} \mathrm{O}$ distribution in ETSP remain to be explored.

Data availability. Raw data presented in this paper can be found in the Supplement.

Supplement. The supplement related to this article is available online at: https://doi.org/10.5194/bg-16-2079-2019-supplement.

Author contributions. DSG developed the experimental design and was co-PI and co-chief scientist of the ASTRA-OMZ cruise. HWB, MIG, XM, DLAM, and DSG conducted field sampling. DG, MA, $\mathrm{XM}$, and DLAM conducted laboratory analyses. QJ and DSG performed data synthesis. QJ, MA, HWB, MIG, XM, DLAM, and DSG prepared the paper.

Competing interests. The authors declare that they have no conflict of interest.

Acknowledgements. The German Federal Ministry of Education and Research (BMBF) grant (03G0243A) awarded to Christa Marandino, Damian Grundle and Tobias Steinhoff supported the ASTRA-OMZ cruise. The BMBF also supported this study as part of the SOPRAN project I and II (03F0611A, 03F0662A). We thank the captain and crew of the R/V Sonne cruise for their technical assistance; Christa Marandino (Chief Scientist) and Tobias Steinhoff for co-organizing the R/V Sonne cruise with Damian Grundle (co-Chief Scientist); and Martina Lohmann, Hanna Campen and Mingshuang Sun for the oxygen and nutrient measurements and help with $\mathrm{N}_{2} \mathrm{O}$ sampling. We thank the Peruvian authorities for allowing us to conduct work in their territorial waters. We thank Tina Baustian for contributing hydrography and $\mathrm{N}_{2} \mathrm{O}$ data off the Peruvian coast. In preparation of the manuscript, Christa Marandino and Lothar Stramma provided constructive comments. Qixing Ji received support from the German Science Foundation (DFG) grants (GR4731/2-1 and MA6297/3-1) awarded to Damian Grundle and Christa Marandino.

Financial support. This research has been supported by the German Federal Ministry of Education and Research (BMBF) (grant nos. 03G0243A, 03F0611A, and 03F0662A) and the Deutsche Forschungsgemeinschaft (DFG) (grant Sonderforschungsbereich 754: Climate-Biogeochemistry Interactions in the Tropical Ocean).

The article processing charges for this open-access publication were covered by a Research Centre of the Helmholtz Association. 
Review statement. This paper was edited by Manmohan Sarin and reviewed by four anonymous referees.

\section{References}

Anderson, J. H.: The metabolism of hydroxylamine to nitrite by Nitrosomonas, Biochem. J., 91, 8-17, 1964.

Arévalo-Martínez, D. L., Kock, A., Loscher, C. R., Schmitz, R. A., and Bange, H. W.: Massive nitrous oxide emissions from the tropical South Pacific Ocean, Nat. Geosci., 8, 530-533, https://doi.org/10.1038/ngeo2469, 2015.

Arévalo-Martínez, D. L., Kock, A., Löscher, C. R., Schmitz, R. A., Stramma, L., and Bange, H. W.: Influence of mesoscale eddies on the distribution of nitrous oxide in the eastern tropical South Pacific, Biogeosciences, 13, 1105-1118, https://doi.org/10.5194/bg-13-1105-2016, 2016.

Babbin, A. R., Bianchi, D., Jayakumar, A., and Ward, B. B.: Rapid nitrous oxide cycling in the suboxic ocean, Science, 348, 11271129, https://doi.org/10.1126/science.aaa8380, 2015.

Barber, R. T. and Chavez, F. P.: Biological Consequences of El Niño, Science, 222, 1203-1210, https://doi.org/10.1126/science.222.4629.1203, 1983.

Blasing, T.: Recent greenhouse gas concentrations, Carbon Dioxide Information Analysis Center (CDIAC), Oak Ridge National Laboratory (ORNL), Oak Ridge, TN, USA, 2016.

Bonin, P., Gilewicz, M., and Bertrand, J. C.: Effects of oxygen on each step of denitrification on Pseudomonas nautica, Can. J. Microbiol., 35, 1061-1064, https://doi.org/10.1139/m89-177, 1989.

Bourbonnais, A., Letscher, R. T., Bange, H. W., Échevin, V., Larkum, J., Mohn, J., Yoshida, N., and Altabet, M. A.: $\mathrm{N}_{2} \mathrm{O}$ production and consumption from stable isotopic and concentration data in the Peruvian coastal upwelling system, Global Biogeochem. Cy., 31, 678-698, https://doi.org/10.1002/2016GB005567, 2017.

Butler, J. H., Elkins, J. W., Thompson, T. M., and Egan, K. B.: Tropospheric and dissolved $\mathrm{N}_{2} \mathrm{O}$ of the west Pacific and east Indian Oceans during the El Niño Southern Oscillation event of 1987, J Geophys. Res.-Atmos., 94, 14865-14877, https://doi.org/10.1029/JD094iD12p14865, 1989.

Carrasco, C., Karstensen, J., and Farias, L.: On the Nitrous Oxide Accumulation in Intermediate Waters of the Eastern South Pacific Ocean, Front. Mar. Sci., 4, 24, https://doi.org/10.3389/fmars.2017.00024, 2017.

Chavez, F. P., Ryan, J., Lluch-Cota, S. E., and Niquen C. M.: From Anchovies to Sardines and Back: Multidecadal Change in the Pacific Ocean, Science, 299, 217-221, https://doi.org/10.1126/science.1075880, 2003.

Cline, J. D., Wisegarver, D. P., and Kelly-Hansen, K.: Nitrous oxide and vertical mixing in the equatorial Pacific during the 1982-1983 El Niño, Deep-Sea. Res., 34, 857-873, https://doi.org/10.1016/0198-0149(87)90041-0, 1987.

Codispoti, L. A. and Christensen, J. P.: Nitrification, denitrification and nitrous oxide cycling in the eastern tropical South Pacific ocean, Mar. Chem., 16, 277-300, https://doi.org/10.1016/03044203(85)90051-9, 1985.

Cornejo, M., Murillo, A. A., and Farías, L.: An unaccounted for $\mathrm{N}_{2} \mathrm{O}$ sink in the surface water of the eastern subtropical South
Pacific: Physical versus biological mechanisms, Prog. Oceanogr., 137, 12-23, https://doi.org/10.1016/j.pocean.2014.12.016, 2015.

Elkins, J. W., Wofsy, S. C., Mcelroy, M. B., Kolb, C. E., and Kaplan, W. A.: Aquatic sources and sinks for nitrous oxide, Nature, 275, 602-606, https://doi.org/10.1038/275602a0, 1978.

Espinoza-Morriberón, D., Echevin, V., Colas, F., Tam, J., Ledesma, J., Vásquez, L., and Graco, M.: Impacts of El Niño events on the Peruvian upwelling system productivity, J. Geophys. Res.-Oceans, 122, 5423-5444, https://doi.org/10.1002/2016JC012439, 2017.

Farías, L., Castro-González, M., Cornejo, M., Charpentier, J., Faúndez, J., Boontanon, N., and Yoshida, N.: Denitrification and nitrous oxide cycling within the upper oxycline of the eastern tropical South Pacific oxygen minimum zone, Limnol. Oceanogr., 54, 132-144, https://doi.org/10.4319/lo.2009.54.1.0132, 2009.

Farías, L., Faúndez, J., Fernández, C., Cornejo, M., Sanhueza, S., and Carrasco, C.: Biological $\mathrm{N}_{2} \mathrm{O}$ Fixation in the Eastern South Pacific Ocean and Marine Cyanobacterial Cultures, PLOS ONE, 8, e63956, https://doi.org/10.1371/journal.pone.0063956, 2013.

Frame, C. H. and Casciotti, K. L.: Biogeochemical controls and isotopic signatures of nitrous oxide production by a marine ammonia-oxidizing bacterium, Biogeosciences, 7, 2695-2709, https://doi.org/10.5194/bg-7-2695-2010, 2010.

Fujii, A., Toyoda, S., Yoshida, O., Watanabe, S., Sasaki, K. I., and Yoshida, N.: Distribution of nitrous oxide dissolved in water masses in the eastern subtropical North Pacific and its origin inferred from isotopomer analysis, J. Oceanogr., 69, 147-157, https://doi.org/10.1007/s10872-012-0162-4, 2013.

Garcia, H. E. and Gordon, L. I.: Oxygen solubility in seawater: Better fitting equations, Limnol. Oceanogr., 6, 1307-1312, https://doi.org/10.4319/lo.1992.37.6.1307, 1992.

Graco, M. I., Purca, S., Dewitte, B., Castro, C. G., Morón, O., Ledesma, J., Flores, G., and Gutiérrez, D.: The OMZ and nutrient features as a signature of interannual and low-frequency variability in the Peruvian upwelling system, Biogeosciences, 14, 4601-4617, https://doi.org/10.5194/bg-14-4601-2017, 2017.

Grundle, D. S., Maranger, R., and Juniper, S. K.: Upper Water Column Nitrous Oxide Distributions in the Northeast Subarctic Pacific Ocean, Atmos. Ocean, 50, 475-486, https://doi.org/10.1080/07055900.2012.727779, 2012.

Grundle, D. S., Löscher, C. R., Krahmann, G., Altabet, M. A., Bange, H. W., Karstensen, J., Körtzinger, A., and Fiedler, B.: Low oxygen eddies in the eastern tropical North Atlantic: Implications for $\mathrm{N}_{2} \mathrm{O}$ cycling, Sci. Rep.-UK, 7, 4806, https://doi.org/10.1038/s41598-017-04745-y, 2017.

Haskell, W. Z., Kadko, D., Hammond, D. E., Knapp, A. N., Prokopenko, M. G., Berelson, W. M., and Capone, D. G.: Upwelling velocity and eddy diffusivity from ${ }^{7} \mathrm{Be}$ measurements used to compare vertical nutrient flux to export POC flux in the Eastern Tropical South Pacific, Mar. Chem., 168, 140-150, https://doi.org/10.1016/j.marchem.2014.10.004, 2015.

Ji, Q., Babbin, A. R., Jayakumar, A., Oleynik, S., and Ward, B. B.: Nitrous oxide production by nitrification and denitrification in the Eastern Tropical South Pacific oxygen minimum zone, Geophys. Res. Lett., 42, 10755-10764, https://doi.org/10.1002/2015GL066853, 2015.

Kock, A. and Bange, H. W.: Counting the ocean's greenhouse gas emissions, Eos, 96, https://doi.org/10.1029/2015EO023665, 2015. 
Kock, A., Arévalo-Martínez, D. L., Löscher, C. R., and Bange, H. W.: Extreme $\mathrm{N}_{2} \mathrm{O}$ accumulation in the coastal oxygen minimum zone off Peru, Biogeosciences, 13, 827-840, https://doi.org/10.5194/bg-13-827-2016, 2016.

Körner, H. and Zumft, W. G.: Expression of denitrification enzymes in response to the dissolved oxygen level and respiratory substrate in continuous culture of Pseudomonas stutzeri, Appl. Environ. Microbiol., 55, 1670-1676, 1989.

Llanillo, P. J., Karstensen, J., Pelegrí, J. L., and Stramma, L.: Physical and biogeochemical forcing of oxygen and nitrate changes during El Niño/El Viejo and La Niña/La Vieja upperocean phases in the tropical eastern South Pacific along $86^{\circ} \mathrm{W}$, Biogeosciences, 10, 6339-6355, https://doi.org/10.5194/bg-106339-2013, 2013.

Mogollón, R. and Calil, P. H. R.: On the effects of ENSO on ocean biogeochemistry in the Northern Humboldt Current System (NHCS): A modeling study, J. Marine Syst., 172, 137-159, https://doi.org/10.1016/j.jmarsys.2017.03.011, 2017.

Mohn, J., Wolf, B., Toyoda, S., Lin, C.-T., Liang, M.-C., Brüggemann, N., Wissel, H., Steiker Amy, E., Dyckmans, J., Szwec, L., Ostrom Nathaniel, E., Casciotti Karen, L., Forbes, M., Giesemann, A., Well, R., Doucett Richard, R., Yarnes Chris, T., Ridley Anna, R., Kaiser, J., and Yoshida, N.: Interlaboratory assessment of nitrous oxide isotopomer analysis by isotope ratio mass spectrometry and laser spectroscopy: current status and perspectives, Rapid Commun. Mass Sp., 28, 1995-2007, https://doi.org/10.1002/rcm.6982, 2014.

Mothet, A., Sebilo, M., Laverman, A. M., Vaury, V., and Mariotti, A.: Is site preference of $\mathrm{N}_{2} \mathrm{O}$ a tool to identify benthic denitrifier $\mathrm{N}_{2} \mathrm{O}$ ?, Environ. Chem., 10, 281-284, https://doi.org/10.1071/EN13021, 2013.

Ñiquen, M. and Bouchon, M.: Impact of El Niño events on pelagic fisheries in Peruvian waters, Deep-Sea Res. Pt., 2, 51, 563-574, https://doi.org/10.1016/j.dsr2.2004.03.001, 2004.

Peng, X., Fuchsman, C. A., Jayakumar, A., Warner, M. J., Devol, A. H., and Ward, B. B.: Revisiting nitrification in the Eastern Tropical South Pacific: A focus on controls, J. Geophys. Res.-Oceans, 121, 1667-1684, https://doi.org/10.1002/2015JC011455, 2016.

Philander, S. G. H.: El Nino Southern Oscillation phenomena, Nature, 302, 295-301, https://doi.org/10.1038/302295a0, 1983.

Popp, B. N., Westley, M. B., Toyoda, S., Miwa, T., Dore, J. E., Yoshida, N., Rust, T. M., Sansone, F. J., Russ, M. E., Ostrom, N. E., and Ostrom, P. H.: Nitrogen and oxygen isotopomeric constraints on the origins and sea-to-air flux of $\mathrm{N}_{2} \mathrm{O}$ in the oligotrophic subtropical North Pacific gyre, Global Biogeochem. Cy., 16, 12-11-12-10, https://doi.org/10.1029/2001GB001806, 2002.

Ravishankara, A., Daniel, J. S., and Portmann, R. W.: Nitrous oxide $\left(\mathrm{N}_{2} \mathrm{O}\right)$ : the dominant ozone-depleting substance emitted in the 21st century, Science, 326, 123-125, https://doi.org/10.1126/science.1176985, 2009.

Rees, A. P., Brown, I. J., Clark, D. R., and Torres, R.: The Lagrangian progression of nitrous oxide within filaments formed in the Mauritanian upwelling, Geophys. Res. Lett., 38, L21606, https://doi.org/10.1029/2011GL049322, 2011.

Revsbech, N. P., Larsen, L. H., Gundersen, J., Dalsgaard, T., Ulloa, O., and Thamdrup, B.: Determination of ultralow oxygen concentrations in oxygen minimum zones by the STOX sensor, Limnol. Oceanogr.-Meth., 7, 371-381, https://doi.org/10.4319/lom.2009.7.371, 2009.

Santoso, A., Mcphaden, M. J., and Cai, W.: The defining characteristics of ENSO extremes and the strong 2015/2016 El Niño, Rev. Geophys., 55, 1079-1129, https://doi.org/10.1002/2017RG000560, 2017.

Silva, N., Rojas, N., and Fedele, A.: Water masses in the Humboldt Current System: Properties, distribution, and the nitrate deficit as a chemical water mass tracer for Equatorial Subsurface Water off Chile, Deep-Sea Res. Pt. 2, 56, 1004-1020, https://doi.org/10.1016/j.dsr2.2008.12.013, 2009.

Stramma, L., Fischer, T., Grundle, D. S., Krahmann, G., Bange, H. W., and Marandino, C. A.: Observed El Niño conditions in the eastern tropical Pacific in October 2015, Ocean Sci., 12, 861873, https://doi.org/10.5194/os-12-861-2016, 2016.

Strub, P. T., Mesías, J. M., Montecino, V., Rutillant, J., and Salinas, S.: Coastal ocean circulation off western south America,, in: The Sea, edited by: Robinson, A. R. and Brink, K. H., John Wiley, New York, 273-313, 1998.

Toyoda, S., Yano, M., Nishimura, S.-i., Akiyama, H., Hayakawa, A., Koba, K., Sudo, S., Yagi, K., Makabe, A., Tobari, Y., Ogawa, N. O., Ohkouchi, N., Yamada, K., and Yoshida, N.: Characterization and production and consumption processes of $\mathrm{N}_{2} \mathrm{O}$ emitted from temperate agricultural soils determined via isotopomer ratio analysis, Global Biogeochem. Cy., 25, GB2008, https://doi.org/10.1029/2009GB003769, 2011.

Toyoda, S., Yoshida, N., and Koba, K.: Isotopocule analysis of biologically produced nitrous oxide in various environments, Mass Spectrom. Rev., 36, 135-160, https://doi.org/10.1002/mas.21459, 2017.

Trimmer, M., Chronopoulou, P.-M., Maanoja, S. T., UpstillGoddard, R. C., Kitidis, V., and Purdy, K. J.: Nitrous oxide as a function of oxygen and archaeal gene abundance in the North Pacific, Nat. Commun., 7, 13451, https://doi.org/10.1038/ncomms13451, 2016.

Walter, S., Breitenbach, U., Bange, H. W., Nausch, G., and Wallace, D. W. R.: Distribution of $\mathrm{N}_{2} \mathrm{O}$ in the Baltic Sea during transition from anoxic to oxic conditions, Biogeosciences, 3, 557-570, https://doi.org/10.5194/bg-3-557-2006, 2006.

Wanninkhof, R.: Relationship between wind speed and gas exchange over the ocean revisited, Limnol. Oceanogr.-Meth., 12, 351-362, https://doi.org/10.4319/lom.2014.12.351, 2014.

Weiss, R. F. and Price, B. A.: Nitrous oxide solubility in water and seawater, Mar. Chem., 8, 347-359, https://doi.org/10.1016/03044203(80)90024-9, 1980.

Well, R., Flessa, H., Jaradat, F., Toyoda, S., and Yoshida, N.: Measurement of isotopomer signatures of $\mathrm{N}_{2} \mathrm{O}$ in groundwater, J. Geophys. Res.-Biogeo., 110, G02006, https://doi.org/10.1029/2005JG000044, 2005.

Winther, M., Balslev-Harder, D., Christensen, S., Priemé, A., Elberling, B., Crosson, E., and Blunier, T.: Continuous measurements of nitrous oxide isotopomers during incubation experiments, Biogeosciences, 15, 767-780, https://doi.org/10.5194/bg15-767-2018, 2018.

Yamagishi, H., Westley, M. B., Popp, B. N., Toyoda, S., Yoshida, N., Watanabe, S., Koba, K., and Yamanaka, Y.: Role of nitrification and denitrification on the nitrous oxide cycle in the eastern tropical North Pacific and Gulf of California, J Geophys. Res.- 
Biogeo., 112, G02015, https://doi.org/10.1029/2006JG000227, 2007.

Yang, S., Gruber, N., Long, M. C., and Vogt, M.: ENSO-Driven Variability of Denitrification and Suboxia in the Eastern Tropical Pacific Ocean, Global Biogeochem. Cy., 31, 1470-1487, https://doi.org/10.1002/2016GB005596, 2017.
Yoshida, N. and Toyoda, S.: Constraining the atmospheric $\mathrm{N}_{2} \mathrm{O}$ budget from intramolecular site preference in $\mathrm{N}_{2} \mathrm{O}$ isotopomers, Nature, 405, 330-334, https://doi.org/10.1038/35012558, 2000. 